\title{
Acoustic investigations of shallow gas in the southern Baltic Sea (Polish Exclusive Economic Zone): a review
}

\author{
Damian Jaśniewicz $^{1}$ (D) $\cdot$ Zygmunt Klusek $^{1} \cdot$ Aleksandra Brodecka-Goluch $^{2} \cdot$ Jerzy Bolałek $^{2}$
}

Received: 29 May 2018 / Accepted: 26 October 2018 / Published online: 14 November 2018

(C) The Author(s) 2018

\begin{abstract}
This paper synthesizes, compares, and discusses acoustic data pertaining to the presence of gas in sediments within the Polish Exclusive Economic Zone in the southern Baltic Sea, which are scattered among different journals, some of which are difficult to access and therefore have limited availability to a wider group of readers. It includes data collected between the 1970s and the present day, collected using different acoustic measurement devices. A majority of reported acoustic manifestations of gas presence in sediments in the Polish EEZ take the form of acoustic blanking followed by layer enhancement, acoustic turbidity, and increased acoustic energy absorption. The observed morphological structures related to gas presence are pockmarks (shallow and buried $-17 \mathrm{~km}^{2}$ ), gas-saturated sediments, gas pockets, and gas chimneys. The estimated total area of acoustic manifestation of shallow gas in the Polish EEZ is around $700 \mathrm{~km}^{2}$. Geochemical analyses of surface sediments demonstrated strong correlation with acoustic data and revealed that methane occurs at relatively shallow depths compared with other regions of the Baltic Sea.
\end{abstract}

\section{Introduction}

Nowadays, methane concentrations in the atmosphere are considered one of the most potent threats to the Earth's climate. Sources of methane to the atmosphere can be anthropogenic (about $64 \%$ of total $\mathrm{CH}_{4}$ in the atmosphere (Saunois et al. 2016)) or natural, with ocean emissions contributing at least 2 to 10\%, if not considerably more (Bange et al. 1994; Bange et al. 1996; Grunwald et al. 2009). Some studies, for example, suggest that the emission from shallow water could contribute as much as $20 \%$ of total methane emission to the atmosphere (Hovland et al. 1993; Fleischer et al. 2001). However, only a small percentage of methane produced in marine sediments reaches the atmosphere (Kiene 1991; Treude 2003). This is due firstly to decomposition during the process of anaerobic oxidation of methane (AOM), which takes place in the sulfate-methane transition zone (SMTZ) located in shallow sediments, and secondly to oxidation and

Damian Jaśniewicz

djasniewicz@iopan.pl

1 Institute of Oceanology, Polish Academy of Sciences, Powstańców Warszawy 55, 81-712 Sopot, Poland

2 Institute of Oceanography, University of Gdańsk, Al. Marszałka Piłsudskiego 46, 81-378 Gdynia, Poland dissolution in the water column during migration toward the sea surface. The estimated total methane flux from the sea to the atmosphere is $8-65 \mathrm{Tg}_{\text {year }}{ }^{-1}$ of $\mathrm{CH}_{4}$ (Hovland et al. 1993) and more contemporary estimates, based on the studies of Kvenvolden et al. (2001) and Judd (2000), give the value of $50 \mathrm{Tg}$ year $^{-1}$ (Judd 2000; Hovland et al. 1993; Kvenvolden et al. 2001). The flux is considered to be highly variable (Schmale et al. 2010).

Continental shelves are regions in which marine methane production takes place on a large scale and evidence for the presence of methane in such areas has been presented in numerous studies around the world (e.g., Laier and Jensen 2007; Fleischer et al. 2001; Schubert et al. 2006; Weschenfelder et al. 2006; Duarte et al. 2007; Huang et al. 2009; Jones et al. 2010; Schneider von Deimling et al. 2010; Garcia-Gil et al. 2011; Weber et al. 2014). The probability of its occurrence is at its highest in coastal regions with significant river inflow, high primary production, and hypoxic/anoxic conditions in bottom waters, which together creates favorable conditions for methanogenesis in sediments (Davis 1992; Claypool and Kaplan 1974). Methane is regarded as the main component of shallow gas in coastal sediments (Claypool and Kaplan 1974). In the context of this study, "shallow gas" refers to gas contained in the surface sediment layer of about $10 \mathrm{~m}$ in thickness.

In the southern Baltic Sea, methane is widely distributed in shallow sediments, especially in the organic-rich muddy 
layers (Albert et al. 1998; Thiessen et al. 2006; Pimenov et al. 2010; Brodecka et al. 2013; Toth et al. 2014a), and also in some areas of the sandy bottom (PIG-PIB et al. 2008; Klusek et al. 1995; Majewski and Klusek 2011). The presence of methane in the marine environment has a considerable impact on its numerous properties, from geochemical conditions in the sediments and surrounding water (Richardson and Davis 1998) to physical background, including acoustic properties (Anderson and Hampton 1980; Wilkens and Richardson 1998; Gardner and Sills 2001) such as reduction of compressional wave speed or scattering and attenuation of the acoustic signal. Gaseous methane in sediments can also influence undersea constructions through modification of the seabed's compressibility and shear strength, affecting the stability and behavior of their foundations (Sills and Wheeler 1992).

Different sources of methane have been distinguished in marine sediments, related to (1) thermogenic processes deep under the marine seabed at temperatures over $50{ }^{\circ} \mathrm{C}$, and (2) biogenic processes in the decomposition of organic matter in shallow sediments (Claypool and Kvenvolden 1983; Barnes and Goldberg 1976; Floodgate and Judd 1992). It is estimated that microbial methane constitutes $80 \%$ of all methane in shallow marine sediments (Fleischer et al. 2001). Methane occurs both in deeper sediments, due to long-term burial processes (Schoell 1988; Breas et al. 2001; Sorokin et al. 2001), and shallow sediments - from the decomposition of biogenic organic matter or as a result of migration from deeper parts through the system of faults and cracks (Floodgate and Judd 1992). The distribution of gaseous methane in sediments is determined by its solubility in given conditions and the sediment matrix. When its concentration exceeds the level of saturation, a portion of it appears in its gaseous form.

Acoustic methods have high capability when it comes to detection of gas in the marine environment, mainly due to the fact that gas has very distinctive acoustic properties in comparison with the surrounding water and sediments (Anderson and Hampton 1980; Wilkens and Richardson 1998). The application of acoustic methods brings beneficial effects which are often hard to achieve by geochemical methods, and they therefore complement each other (Fleischer et al. 2001). Some advantages of the acoustic methods include greater coverage than with point sampling, continuous measurement over the area of interest in a relatively short time, and relatively low cost. Additionally, acoustic measurements are non-invasive and do not cause any alteration in the geological, chemical, and physical properties of sediments, as is often an issue with invasive methods.

The results of numerous acoustic investigations concerning shallow gas occurrence in the Polish Exclusive Economic Zone (Polish EEZ, southern Baltic Sea) are scattered among a number of different local periodicals, sometimes difficult to access, and this definitely restricts their availability to a wider group of readers. In the current paper, attempts have been made to synthesize, compare, and discuss those scattered results, and also to complement and verify them with geochemical results. By bringing together the results from different publications where various acoustic methods were applied, we can present a more detailed and broader view on methane presence in the sediments and seawater of the southern Baltic Sea (Polish sector).

\section{Study area}

The Polish Exclusive Economic Zone (EEZ) is located in the southern part of the Baltic Sea and covers the following areas: the Gulf of Gdańsk, the Gdańsk Deep, the southern part of the Gotland Deep, the Słupsk Bank, the Słupsk Furrow, and the Pomeranian Bight. The thickness of all sedimentary deposits above the crystalline base in this region is estimated to be from 2400 to $3100 \mathrm{~m}$ (PIG-PIB et al. 2008), with the thickness of the latest Quaternary deposits being between 20 and $50 \mathrm{~m}$ in the Gdańsk Basin and prevailingly $>20 \mathrm{~m}$ in the Stupsk Furrow, except for its southeastern part where the thickness is less than $10 \mathrm{~m}$ (Uścinowicz 1995; PIG-PIB et al. 2008). The two biggest river estuaries in the Polish EEZ are located in the Pomerania Bight (River Oder) and the Gulf of Gdańsk (River Vistula), with high organic matter and nutrient input leading to intensive primary production $\left(190 \mathrm{~g} \mathrm{C} \mathrm{m}^{-2}\right.$ year $^{-1}$ in the Gulf of Gdańsk (Witek et al. 1999; Majewski 2013; Kowalik 2016). Seasonal stratification of water masses, anoxic conditions near the sea bottom, and high organic matter supply to the sediments (Eysiak-Pastuszak and Drgas 2004; Brink and Robinson 2005; Witek et al. 1997; Hansson et al. 2011) create favorable conditions for methanogenesis. The rate of sedimentation in the Polish part of the southern Baltic Sea is varied, on average from $1.5 \mathrm{~mm}_{\text {year }}{ }^{-1}$ to $2.0 \mathrm{~mm}_{\text {year }}{ }^{-1}$ in the Gdańsk Deep, between 1.5 and $3.6 \mathrm{~mm}$ year $^{-1}$ in the Gulf of Gdańsk, $0.62 \mathrm{~mm} \mathrm{year}^{-1}$ in the Słupsk Furrow, and 0.35$0.95 \mathrm{~mm} \mathrm{year}^{-1}$ in the Bornholm Deep (Szczepańska and Uścinowicz 1994; Mojski et al. 1995; Suplińska and Pietrzak-Flis 2008).

Sediments close to the stretch of Polish coastline which runs from the Pomeranian Bight to the Hel Peninsula consist mainly of fine- and medium-grained sands, together with local admixture of pebbles and stones (more common in the west, Fig. 1). In the northwestern part of the Polish EEZ (from the vicinity of Kołobrzeg $\sim 15^{\circ} 20^{\prime} \mathrm{E}$ to the northwestern part of the Słupsk Bank $\sim 16^{\circ} 20^{\prime} \mathrm{E}$ ), large areas of the seabed consist of silts (mixed with sands at depths of about $60 \mathrm{~m}$ ) and clays (deepest parts) (Fig. 1), while the northern part of the Słupsk Bank is covered with a sand-pebble-stone mixture. In the Shupsk Furrow (depths $>60 \mathrm{~m}$ ), the central part is covered by silts, the northern part by clays, and the southern part by sands of mixed grain size, together with gravel, pebbles, and stones (Fig. 1). Sediments in this region are poorly sorted in 


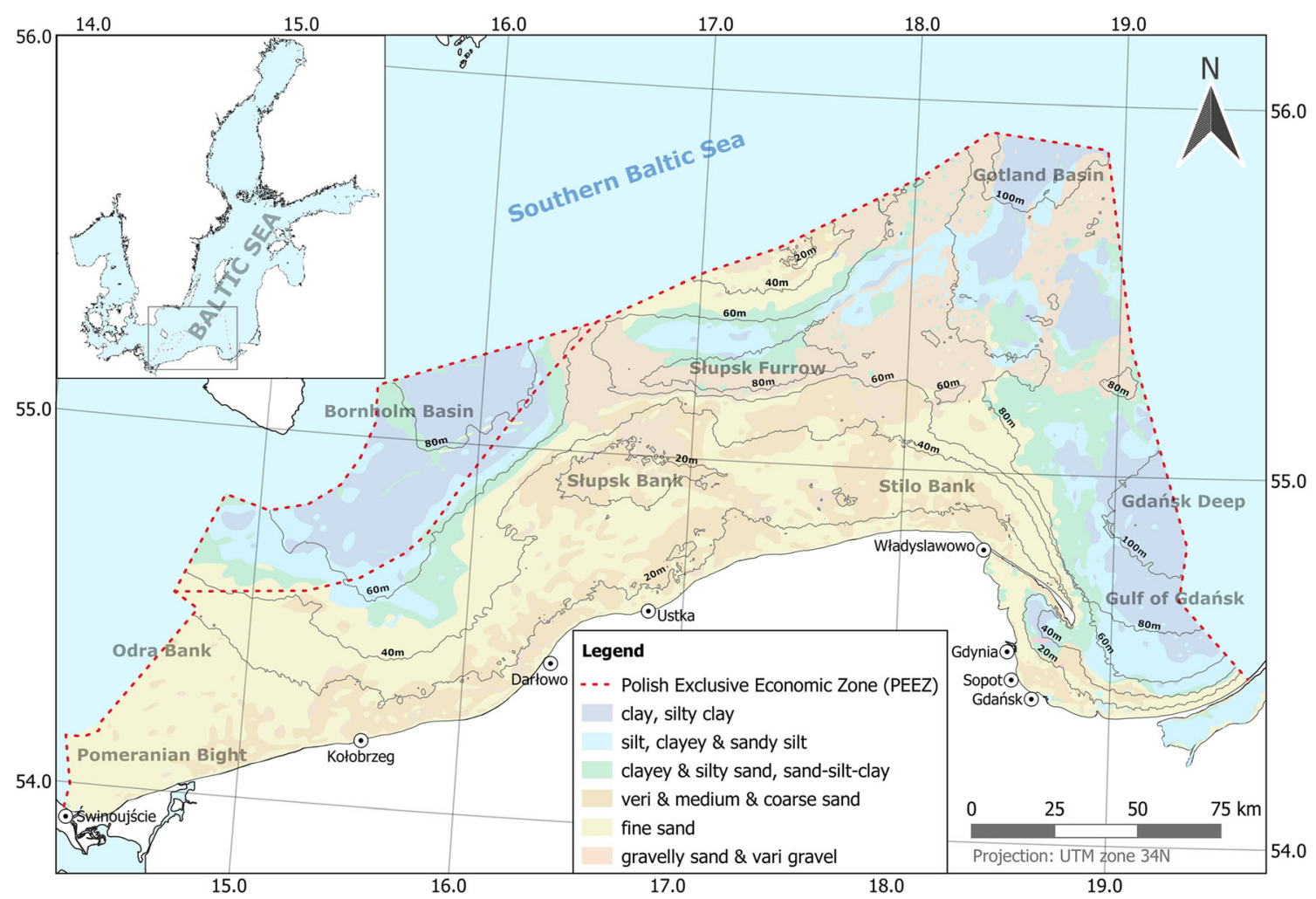

Fig. 1 Map of the study area with borders of Polish EEZ (red dashed line) and surface sediment coverage (based on Mojski 1995, Plate XXIV)

comparison to sediments in regions such as the Gdańsk Basin (PIG-PIB et al. 2008). To the north of the Stupsk Furrow, sediments containing fine- and medium-grained sands and sand mixed with gravel are present, gradually giving way to silts towards the east (Gotland Deep). The southern part of the Gotland Deep is covered mostly by silts and clays, with some scattered spots of fine silty sands. The central part of the Gdańsk Deep is covered with clays and silts, which give way to fine- and medium-grained sands in shallower southwestern regions closer to the coast (Mojski et al. 1995; Fig. 1). Silts that are present in this region were accumulated during the period of the Yoldian Sea, Ancylus Lake, and Littorina Sea in Holocene (e.g., Emelyanov 2002; Kostecki and JanczakKostecka 2012) and now form a layer about $20 \mathrm{~m}$ thick above deeper deposits of clays and coarser-grained material (Mojski 1995; Emelyanov 2002). In general, silts and clays in the Polish EEZ can be found in the areas where the sea depth is greater than $60 \mathrm{~m}$ (PIG-PIB et al. 2008). Seismic data showed increasing thickness of post-Permian sediment layers from the Gdańsk Deep toward the Pomeranian Bight, and from the open sea toward the coast (PIG-PIB et al. 2008).

\section{Geochemical background}

Chemical analyses indicated that dissolved methane was present in the near-bottom water of the area to the east of $18^{\circ} 00^{\prime} \mathrm{E}$ in concentrations ranging from several dozen nanomoles per cubic decimeter up to about 1$2 \mu \mathrm{mol} \mathrm{dm}{ }^{-3}$ (PIG-PIB et al. 2008). In regions with depths greater than $50 \mathrm{~m}$ and fine-grained bottom sediments, the methane dissolved in near-bottom water reached as high as $4 \mu \mathrm{mol} \mathrm{dm}{ }^{-3}$ (PIG-PIB et al. 2008). In general, the highest concentrations of methane in sediment samples collected by PIG-PIB in the western and central parts of the Polish EEZ were registered in the deepest areas (Bornholm Basin, Shupsk Furrow) and these were up to a few cubic centimeters per kilogram. Geochemical analysis based on core sampling in the eastern part of the Polish EEZ (Gulf of Gdańsk, Gdańsk Deep) indicated methane presence in shallow sediments at 12 out of 16 stations, with the SMTZ ranging from 10 to $20 \mathrm{~cm}$ to $15-55 \mathrm{~cm}$ below the sediment surface. At sediment depths of $35-40 \mathrm{~cm} \mathrm{bsf}$ (below sea floor), methane concentrations were on average 6-8 $\mathrm{mmol} \mathrm{dm}^{-3}$ (Brodecka et al. 2013). The depth of the SMTZ in the eastern part of the Polish EEZ is relatively shallow in comparison to sediments in other regions of the Baltic Sea (Whiticar 2002; Martens 1999; Iversen and Jorgensen 1985; Piker et al. 1998; Thomsen et al. 2001). Geochemical multiparameter analyses showed that methane present in shallow sediments of the Gdańsk Basin originates mainly from the anaerobic decomposition of organic matter, although the contribution of methane from deeper sediments cannot be excluded (Brodecka et al. 2013). 


\section{Shallow gas manifestation in the context of acoustic methods}

Methane in marine sediments can be present in two forms: dissolved or gaseous (bubbles). It has been estimated that hydrocarbon-bearing sediments can constitute up to $30 \%$ of continental shelves (St. John 1984), which have high potential for gas accumulation (Hovland et al. 1993). Due to the distinctive acoustic properties of sediments filled with gas, this allows acoustic detection to be applied (Schüler 1952; Anderson and Hampton 1980; Abegg and Anderson 1977). From the acoustic point of view, gaseous sediments can be characterized by high acoustic impedance contrast and elastic contrast (in relation to the surrounding medium - non-gaseous sediments or water) determining high acoustic energy scattering properties. The presence of gassy sediments or bubbles in seawater can also be detected based on higher attenuation of acoustic energy, or by reduction of acoustic signal propagation speed (Anderson and Hampton 1980; Wilkens and Richardson 1998). Different acoustic devices or setups, having different characteristics, demonstrate better or worse efficiency for different objectives, depending also on the environment layout (Table 1).

Acoustic manifestations of gas presence are influenced by the concentration of gas, the form of distribution, and the applied measurement method. In sediments, gas may occur as (1) interstitial bubbles (between adjacent sediment particles), (2) reservoir bubbles (between many sediment particles), and (3) bubbles which displace surrounding sediments. Most bubbles seem to be of the second and third types, as examined based on the collected sediment samples (Jackson and Richardson 2007; Anderson et al. 1998; Best et al. 2004, Boudreau et al. 2005).

Gassy sediments manifest themselves in acoustic imaging through (Fig. 2):

1. Acoustic turbidity - chaotic reflections on gas intrusions with variant extent leading to layer blurring.

2. Layer enhancement-high coherent reflection, forming high acoustic amplitude horizons.

3. Acoustic blanking - masking of underlying layers beneath gassy sediments due to high attenuation and/or high reflection from the above layer.

4. Downward bent/shift of layers in the vicinity of acoustic blanking areas - due to velocity reduction which results in the delay of an acoustic signal returning from a particular layer.

5. Reversed polarity of back reflected signals - reflection with the negative phase of acoustic signals as a result of negative impedance of gaseous intrusion (in relation to sediments).

6. Reverberation of the acoustic signal - the result of acoustic excitation of gas and prolongation of the acoustic signal deriving from it. Observed as relatively close multiples (in acoustic imaging) visible as reflections with gradually decreasing amplitude.

7. Inhomogeneity of sediment layering - the effect of a sudden change of scattering, reflectivity, or sound speed in sediments as corresponding change of gas concentration and/or distribution.

Table 1 Capabilities and advantages of the acoustic devices

\begin{tabular}{|c|c|c|}
\hline Acoustic device & Capabilities and advantages & Examples \\
\hline $\begin{array}{l}\text { Single beam, single- or } \\
\text { multifrequency } \\
\text { echosounder }\end{array}$ & $\begin{array}{l}\text { Low frequencies - vertical sub-bottom profile and relative assess- } \\
\text { ment of gaseous layer in relation to sediment layering; depth of } \\
\text { gaseous layer assessment }\end{array}$ & $\begin{array}{l}\text { Greinert et al. 2006; Westbrook et al. 2009; Majewski } \\
\text { and Klusek 2014; Toth et al. 2014a }\end{array}$ \\
\hline $\begin{array}{l}\text { Multibeam sonar and } \\
\text { echosounder }\end{array}$ & $\begin{array}{l}\text { High frequencies-large coverage area of sediment surface layer, } \\
\text { strong signal enhancement from sediments with shallow gas } \\
\text { layer; high sensitiveness for gas seeping detection; detailed sur- } \\
\text { face geomorphological structure } \\
\text { Low and mid frequency multibeam sonars (some tens of } \mathrm{kHz} \text { ) - } \\
\text { strong penetration for sub-bottom gas detection in a wide swath }\end{array}$ & $\begin{array}{l}\text { Jørgensen and Fossing 2012; Schneider von Deimling } \\
\text { et al. } 2013\end{array}$ \\
\hline $\begin{array}{l}\text { Chirp echosounder } \\
\text { (broadband) }\end{array}$ & $\begin{array}{l}\text { High resolution; capability of measuring different manifestations of } \\
\text { methane occurrence: geomorphology of pockmarks, gas seeps, } \\
\text { and ebullitions, gas pocket, gas chimneys (beneath pockmarks) }\end{array}$ & Orange et al. 2005; Duarte et al. 2007; \\
\hline Side-scan sonar & $\begin{array}{l}\text { High resolution, surface geomorphology, wide area of coverage, } \\
\text { visible gas seeping }\end{array}$ & Garcia-Gil et al. 2002; Brodecka et al. 2013 \\
\hline $\begin{array}{l}\text { Boomer, sparker, and } \\
\text { air gun }\end{array}$ & $\begin{array}{l}\text { Very deep penetration (disadvantage: lower resolution than higher } \\
\text { frequency methods), deep geomorphological mapping, lower } \\
\text { shadowing of underlying layers }\end{array}$ & $\begin{array}{l}\text { Park et al. 1999; Garcia-Gil et al. 2002; Baltzer et al. } \\
\text { 2005; Diez et al. 2007; Iglesias and García-Gil 2007; } \\
\text { Toth et al. 2014b }\end{array}$ \\
\hline Non-linear methods & $\begin{array}{l}\text { Assessment of gas bubble concentration (using two close } \\
\text { frequencies } \Delta f \approx 10 \% \text { for excitation and measuring response at } \\
\text { those two excitation frequencies, summation and differential } \\
\text { frequencies) }\end{array}$ & $\begin{array}{l}\text { Klusek et al. 1995, Boyle et al. 1998, Tęgowski et al. } \\
\text { 2003, Tegowski and Zieliński } 2006\end{array}$ \\
\hline High-frequency bistatic & Improvement of estimation of gas bubble population in sediments & Chu 1997 \\
\hline
\end{tabular}


Fig. 2 Acoustic manifestations of gas in the Gdańsk Basin (Fig. 3): a homogenous regular area of gas presence [1]; b side-scan sonar image of active pockmark (based on Majewski 2014, [2]); c area with multiple strong acoustic indications of gas presence and active pockmark [3]; $\mathbf{d}$ ascending gas bubbles in the water column [4]; e spot-like distribution of gas presence in sediments [41]
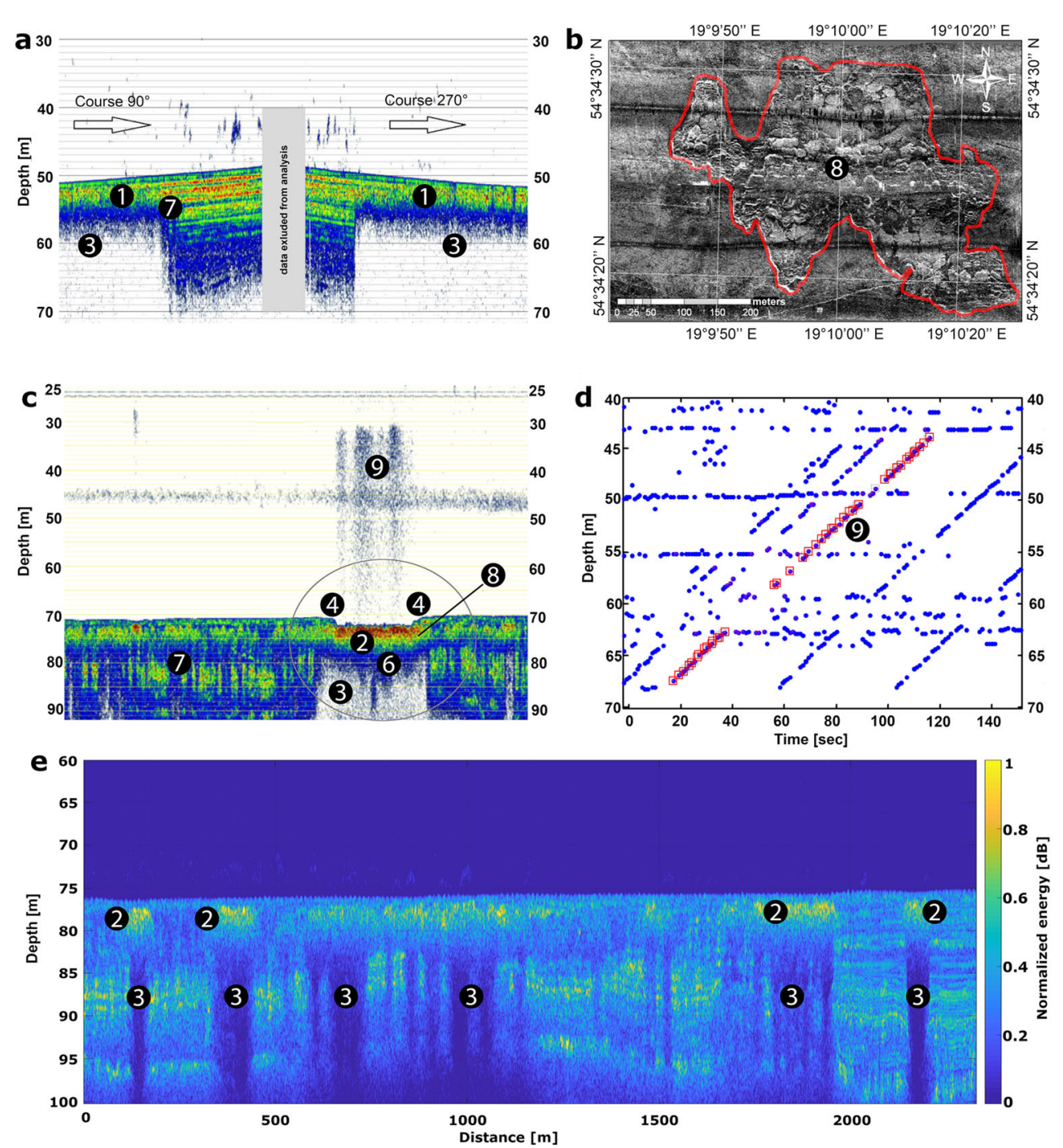

8. Pockmarks (characteristic echo sounding profile of sea bottom)-geomorphological structures formed as a result of gas leaking through sediments and/or accumulation of the third type of gas bubbles affecting the structure of sediments mechanically.

9. Acoustic "flares" in echosounder images from the waterbody-high backscattering of an acoustic signal on a cloud of gas bubbles in water expresses gas fluxes from the sea bottom, an indirect indication of gas presence in the sea bottom.

The abovementioned types of gas presence manifestations in the marine environment are shown in Fig. 2 with corresponding numbering (black dots). Figure 2 contains data gathered and processed by the authors of this paper. The general capabilities, advantages, and characteristics of different types of hydroacoustic devices used in the assessment of gaseous methane are presented in Table 1.

Different manifestations of gas occurrence, as shown in Fig. 2, can co-exist with each other, change gradually or abruptly in space dimension, and undergo temporal variations (month to years). For example, Fig. 2a presents an echogram (obtained by single-beam echosounder) characterized by strong acoustic blanking (3) and acoustic turbidity (1), in contrast to the image of unaltered layers (in the center). This kind of manifestation of gas presence is regularly observed with the homogeneous presence of gas over a large area [1] in Puck Bay. Figure $2 \mathrm{~b}$ shows an acoustic image (mosaic) of the sediment surface (obtained by side-scan sonar). The red line marks a widespread area classified as pockmark (8; seen also on Fig. 2c), which is characterized by distinct surface pattern structure and with characteristic acoustic backscattering [2] (Gulf of Gdańsk). Figure 2c presents an echogram with 
visualization of the uppermost sediments in an area with active (9; gas seeps) pockmark (8). The various effects of gas occurrence in sediments which distort the acoustic signal in characteristic ways $(2,3,4,6,7)$ are evident [3] (Gulf of Gdańsk). Figure 2d presents the behavior of objects (blue dots) with significant target strength (acoustic backscattering), in a water column $[\mathrm{m}]$ in domain of time $[\mathrm{s}]$. Against a background of stable (in time) scattering layers (such as plankton), we register relatively fast ascent of gas bubbles (examples are marked by red squares). This event is classified as a gas seep (9) and occurs over an area with a significant amount of gas in sediments [4] (Gulf of Gdańsk). Figure 2e (echogram) presents the case of rapid and irregular changes of gaseous sediment presence in the Gulf of Gdańsk [41], as manifested by acoustic blanking (3) and backscattered signal enhancement (2) from the uppermost layers of sediments.

\section{Methane in sediments of the southern part of the Baltic Sea}

One of the best documented areas of the Baltic Sea in terms of geochemical and hydroacoustic investigations on methane is the Eckernförde Bay, for which the first studies presenting acoustic evidence of methane presence in sediments date back to the 1950s (Schüler 1952; Edgerton et al. 1966; Abegg and Anderson 1977). The prevalent acoustic manifestations of gas in the Eckernförde Bay are acoustic turbidity and acoustic blanking in sediments (Wever and Fiedler 1995; Whiticar 1982; Albert et al. 1998; Wever et al. 1998). The sulfatemethane transition zone (SMTZ) is located on average at depths of around 20-150 cm below the sediment surface (Bussmann et al. 1999; Whiticar et al. 2002). Strong correlation between acoustic anomalies and methane presence in the Eckernförde Bay was proven in studies carried out by Anderson et al. (1998).

In the Arkona Basin, characterized by post glacial finegrained sediments rich in organic material, a $1500-\mathrm{km}^{2}$ area of acoustic turbidity was reported by Thiessen et al. (2006) with methane concentrations reaching $7.7 \mathrm{mmol} \mathrm{dm}^{-3}$. Other acoustic manifestations of gas presence in the sediments of this area include decreasing sound velocity and reverse polarity of seismic signals at depths of decreased acoustic impedance in highly saturated sediments (Mathys et al. 2005).

In the Bornholm Deep, the SMTZ is typically located within the uppermost $50 \mathrm{~cm}$ of muddy sediments (Jørgensen and Fossing 2012; Toth et al. 2014b). The manifestations of gaseous methane in sediments of this area (acoustic turbidity, acoustic blanking in acoustic data and polarity changes, reverberations, multiples and interference) have been assessed using various acoustic tools (Jørgensen and Fossing 2012; Toth et al. 2014a, b). Recent studies (Gülzow et al. 2014) have shown that the Bornholm Basin is subject to significant seasonal changes in terms of methane concentration. Extensive areas of shallow gas (2-4 m bsf) were reported by Laier and Jensen (2007), both in the Bornholm Basin and in the Arkona Basin.

In the area of the Gotland Deep, methane concentration in sediments was shown (Piker et al. 1998) to rise exponentially from $0 \mathrm{mmol} \mathrm{dm}{ }^{-3}$ in surface sedimentary layers to $3 \mathrm{mmol} \mathrm{dm}{ }^{-3}$ at $80 \mathrm{~cm}$ bsf. The methane concentrations in the eastern waters of the Gotland Deep range from $10 \mathrm{nmol} \mathrm{dm}{ }^{-3}$ at $70 \mathrm{~m}$ depth up to $160 \mathrm{nmol} \mathrm{dm}^{-3}$ at $180 \mathrm{~m}$, and are relatively high (Schmale et al. 2010). A study carried out by Ulyanova et al. (2012) showed that pockmarks located in the southern part of the Gotland Deep (Russian EEZ) have morphological features of pockmarks but without the typical acoustic anomalies associated with such formations. The profiles of methane concentrations in these pockmarks resemble those found in the gassy mud sediments of the Gdańsk Deep (about $3 \mathrm{mmol} \mathrm{dm}{ }^{-3}$ at $25 \mathrm{~cm}$ bsf) as opposed to typical pockmarks. In the Russian EEZ, located mostly in the Gdańsk Deep region but also including a small southern part of the Gotland Deep, $245 \mathrm{~km}^{2}$ of acoustic anomalies caused by gaseous methane was reported by Pimenov et al. (2010). More recent studies report $300 \mathrm{~km}^{2}$ of acoustic anomalies associated with gas presence, supported by core sampling at 21 stations (Ulyanova et al. 2012), and many of these anomalies (acoustic blanking and acoustic turbidity) have been attributed to pockmarks or interstitial saturation with gas. The total area of discovered pockmarks amounts to $1.7 \mathrm{~km}^{2}$, they have an average depth of $1-$ $3 \mathrm{~m}$ and width of up to $200 \mathrm{~m}$ (Ulyanova et al. 2012). The biggest pockmark reported in this region is $1 \mathrm{~km}^{2}$ with possible gas ebullition, and the concentration of methane can be up to $4 \mathrm{mmol} \mathrm{dm}{ }^{-3}$ at between 20 and $100 \mathrm{~cm}$ bsf (Pimenov et al. 2010). Pockmarks usually occur in groups and are characterized by high methane fluxes, going up to as much as $3.3 \mathrm{mmol} \mathrm{m}^{-2}$ day $^{-1}$ (Ulyanova et al. 2012). Methane concentrations determined in the sediments of this area usually exceed $1 \mathrm{mmol} \mathrm{dm}{ }^{-3}$ within the uppermost $100 \mathrm{~cm}$ of sediment (Pimenov et al. 2010) and are within a range of 1 to $1000 \mu \mathrm{mol} \mathrm{dm}{ }^{-3}$ in the top $2 \mathrm{~cm}$ of sediment (Ulyanova et al. 2014). Seasonal variabilities of methane fluxes from sediments into water are commonly observed (Ulyanova et al. 2014) with the highest registered fluxes of $2.48 \mathrm{mmol} \mathrm{m}^{-2}$ day $^{-1}$ in the Curonian Lagoon during the warm period, and the lowest during the cold period $\left(0.002 \mathrm{mmol} \mathrm{m}^{-2} \mathrm{day}^{-1}\right)$. The total flux for the Russian EEZ was estimated to be $280 \times 10^{6} \mathrm{mmol} \mathrm{day}^{-1}$ (Ulyanova et al. 2012).

\section{Acoustic studies on shallow gas in the Polish part of the Baltic Sea (Polish Exclusive Economic Zone, EEZ)}

In studies conducted in the early 1990 s, some suggestions were made about the existence of free gas bubbles and 
gaseous structures in the bottom sediments of the Gdańsk Basin (Jankowska 1993; Geodekyian et al. 1990; Klusek et al. 1993, 1995). Those suggestions were later reinforced by acoustic (Orłowski 2009; Jakacki et al. 2002; Tegowski et al. 2003; Majewski and Klusek 2011, 2014, Table 1) and geochemical investigations (Brodecka et al. 2013). In 2008, the Polish Geological Institute (PIG-PIB et al. 2008) presented a report based on 96 seismic profiles (2288 km in total) collected in the 1970s and 1980s in the western part of the Polish Exclusive Economic Zone (coverage area to the west from $18^{\circ} 00^{\prime} \mathrm{E}$ ), which was aimed at assessing petroleum prospectivity in the studied area and presented maps of geogenic contamination of the sea bottom. These data were complemented with the results of geochemical analyses (carried out in 2005-2007), which provided information about shallow methane. Moreover, some supplementary data, both unpublished and published, exist on acoustic manifestation of shallow gas in regions of the Słupsk Furrow, Słupsk Bank (Brodecka et al. 2013; Majewski 2014) and the Bornholm Deep (Orłowski 2009).

The most common forms of acoustic manifestation of gaseous methane in the sediments of the Polish EEZ are as follows: acoustic turbidity, acoustic blanking, and enhancement reflectivity. In addition, several specific geomorphological structures, i.e., pockmarks and gas pockets, were found in the Polish part of the Gdańsk Deep (Majewski and Klusek 2011, 2014; Brodecka et al. 2013). In total, $578 \mathrm{~km}^{2}$ of the bottom area has been acoustically classified as gas-bearing sediments $\left(24.6 \mathrm{~km}^{2}\right.$ were pockmarks $)$ by Majewski and Klusek $(2011,2014)$ and Majewski (2014). These results were further supported by geochemical analyses (Brodecka et al. 2013). Seventeen percent $\left(4500 \mathrm{~km}^{2}\right)$ of the Polish EEZ is estimated to have conditions which allow gas seeps (Orłowski 2009). However, only a few gas seep events were registered in the form of gas flares (Orłowski 2009; Majewski 2014; Fig. 2d). The system of faults present in the sea bottom, clearly visible in seismic data (PIG-PIB et al. 2008), may be the reason for methane migration from deeper sediments and its common occurrence in shallow sediments of the Polish EEZ area.

Detailed results of acoustic investigations in the Polish EEZ, grouped by regions, are presented in Table 2. Some acoustic results presented in the text and table have assigned [<number>] indicator (e.g., Fig. 2a-d: [1],[2],[3],[4]) and are plotted on Fig. 3 and/or Fig. 4 as black area marks (Figs. 3 and 4-legend: "acoustic studies [no.]"). In Figs. 3 and 4, areas where acoustic surveys conducted during years 2009-2017 show no sign of shallow gas are also presented (net gray polygon). However, the depth of bellow seafloor sediment acoustic imaging was highly dependable on type of sediments, producing data with max depth of proper quality data varying between 3 and $30 \mathrm{~m}$ (assuming the speed of sound $c$ as in nearbottom water). Based on the current level of knowledge, the estimated area of shallow gas presence in the PEEZ is $700 \mathrm{~km}^{2}$. This estimation was based on data in possession of IOPAS and results gathered from reviewed articles. Spatial interpolation was carried out on the IOPAS data based on parallel acoustic profiles (200 to $800 \mathrm{~m}$ interspace) together with perpendicular profiles to create a grid covering the area of interest. The data from the reviewed articles were digitized, georeferenced, and later introduced to the GIS environment along with the IOPAS data, at which point spatial analysis took place. Figures. 3 and 4 show the results of this process. The results of geochemical analyses presented in this paper serve as a background for the discussion of acoustic data. Only exemplary methane concentration values for different research areas within the PEEZ are given in the present study. Detailed description of geochemical surveys and discussion of the obtained results can be found in the cited publications.

\section{Gulf of Gdańsk}

There are numerous publications concerned with methane presence in the sediments of the Gulf of Gdańsk, based both on geochemical and acoustic investigations, which indicate strong correlation between acoustic and geochemical results (Klusek et al. 1993, 1995; Jakacki et al. 2002; Tęgowski et al. 2003; Rudowski et al. 2010; Majewski and Klusek 2011; Brodecka et al. 2013).

In the southwestern part of the Gulf of Gdańsk, the typical manifestations of gas presence are the following: acoustic blanking (most dominant- 12 and $38 \mathrm{kHz}$ data), acoustic turbidity, enhanced reflection, and negative phase presence (Majewski and Klusek 2011). Geochemical analyses carried out in 2010-2011 showed that methane was present in the pore waters of shallow sediments and that the SMTZ occurred at depths of 10-20 cm bsf (Brodecka et al. 2013). A study by Klusek et al. (2010) showed that in the region where core sampling was conducted (Brodecka et al. 2013), the marine clay-silt sediments containing gas had a different bottom backscattering strength than that predicted on the basis of the Johnson bottom scattering model [26] (Jackson 1987). The stations without gas were in good keeping with the model. Acoustic blanking, registered by means of a single-beam subbottom profiler, was found to occur at depths of 1 to $4 \mathrm{~m}$ below the sediment surface (Majewski and Klusek 2011). In general, the region extending southwards from the tip of the Hel Peninsula (southwestern Gulf of Gdańsk) is characterized by extensive and irregular occurrence of acoustic manifestations of gas presence $[5,6,7,8]$ (Tęgowski et al. 2003; Majewski and Klusek 2011; Table 2) with strong spatial differences of estimated microbubble concentrations [6] (Tegowski et al. 2003) and rapid changes from acoustic permeability to acoustic blanking (Majewski and Klusek 2011). The rapid changing from acoustic blanking to acoustic window (permeability) which occurs in this region is most likely 
Table 2 Acoustic reports on gas presence in the Polish EEZ

\begin{tabular}{|c|c|}
\hline Area & Finding \\
\hline $\begin{array}{l}\text { Gulf of Gdańsk } \\
\text { (Puck Bay) }\end{array}$ & $\begin{array}{l}\text { Highest gas concentration in silty clay } \\
\text { sediments }\left(300 \mathrm{~m}^{-3} \mu \mathrm{m}^{-1} \text { for } 29.8 \text { and }\right. \\
33.2 \mathrm{kHz} \text { ) and lowest for clayey silt and } \\
\text { glacial clay (non-linear method) [5] } \\
\text { Estimated number of resonance bubbles } \\
300 \mathrm{~m}^{-3} \mu^{-1} \text { for } 100 \text { and } 110 \mathrm{kHz} \text { in the } \\
\text { uppermost surface layer of sediments [6] } \\
\text { Acoustic blanking and acoustic turbidity. } \\
\text { Acoustic curtains in the water column } \\
\text { (supposed gas ebullitions). } \\
\text { Geomorphological structures connected with } \\
\text { gas presence } \sim 35 \mathrm{~km}^{2} \text { [7] } \\
\text { Backscattering strength difference from } \\
\text { clay-silt sediments containing gas [26] } \\
\text { Acoustic blanking (manifestation of gas } \\
\text { presence) [39] }\end{array}$ \\
\hline
\end{tabular}

Equipment

Publication

Two transducers with frequencies of $29.8 \mathrm{kHz}$ Jakacki et al. 2002 and $33.2 \mathrm{kHz}$

Set of transducers: $30.4 \mathrm{kHz}, 33.6 \mathrm{kHz}$, $105.5 \mathrm{kHz}$, and $115 \mathrm{kHz}$

Seabed Oretech 3010-S (3.5 and $5 \mathrm{kHz}$ ), side-scan sonar Edge Tech DF1000

Tęgowski et al. 2003

Rudowski et al. 2010

Chirp $40-60 \mathrm{kHz}$

Kongsberg EA400 echosounder ( $38 \mathrm{kHz}$ and $200 \mathrm{kHz}$ ), Odom MK III echosounder $(12 \mathrm{kHz})$

Gulf of Gdańsk Acoustic blanking, acoustic turbidity, enhanced reflection negative phase presence (manifestation of gas presence) $\sim 156 \mathrm{~km}^{2}$ [8]

Mapping large areas of gas saturated sediments (with extensive and irregular nature) $\sim 15.6 \mathrm{~km}^{2}[9,27]$

Estimation of active gas seeps area $\left(0.6 \mathrm{~km}^{2}\right)$ [10]

Numerous small (few meters) gas pockets [28]

Three groups of pockmarks $\left(8.1 \mathrm{~km}^{2}\right)$. Extensive gas saturated areas around them [11]

Continuous (few hours) gas seeps from the seabed, registered as gas flares near the tip of Hel Peninsula [12]. Estimation of the average rise velocity- $0.22 \mathrm{~m} \mathrm{~s}^{-1}$

Seeps from gas pockets in sediments and gas saturated sediments [16]

Gdańsk Deep Acoustic blanking (strong attenuation), acoustic turbidity, enhanced reflection (different manifestation of gas presence in sediments) [13]

Buried pockmarks $\left(16.5 \mathrm{~km}^{2}\right)$ [14] hirp (40-60 and 40-80 kHz), Kongsberg EA400 echosounder (38 kHz and $200 \mathrm{kHz})$, Odom MK III echosounder (12 kHz)

Chirp (40-60 and 40-80 kHz), Kongsberg EA400 echosounder (38 kHz and $200 \mathrm{kHz})$, Odom MK III echosounder (12 kHz), Edgetech DF-1000 side-scan sonar (100 kHz and $500 \mathrm{kHz}$ ), Simrad EK-60 Echosounder (70, 120, $200 \mathrm{kHz})$

Odom MK III echosounder (12 kHz), side-scan sonar $(100 \mathrm{kHz}$ and $500 \mathrm{kHz})$

38-kHz echosounder (RV Baltica)

Klusek et al. 2010

Majewski 2014

Majewski 2014; Majewski and Klusek 2011, 2014

Majewski 2014; Klusek and Majewski 2012; Brodecka et al. 2013; Majewski and Klusek 2011, 2014

Majewski 2014; Majewski and Klusek 2011; Brodecka et al. 2013

Orłowski 2009

Odom MK III echosounder (12 kHz), 38 kHz echosounder

Chirp (40-60 and 40-80 kHz) multibeam echosounder (300 kHz) Odom MK III echosounder $(12 \mathrm{kHz})$

Odom MK III echosounder (12 kHz)

Gas seeps, average speed of rising $0.24 \mathrm{~m} \mathrm{~s}^{-1}, \quad 38 \mathrm{kHz}$ echosounder (RV Baltica) size changes during migration [15]

Gdańsk Basin Usefulness of signal parameterization for gassy (Gulf of Gdańsk sediment classification [17] and Gdańsk Deep)

Stilo Bank

Gotland Basin (southern)

Acoustic anomalies connected with gas presence: acoustic blanking and layer enhancement $[30,31]$

2 acoustic flares as a result of gas seeps ( $T=\sim 200 \mathrm{~s})$-2 different forms [18]

Gas diffusion chimney, gas crater, 1.4-km-wide area of acoustic blanking [19]

Słupsk Furrow and Acoustic blanking: from tens of centimeters Słupsk Bank [20] (east) to $10 \mathrm{~m}$ (west) $89.2 \mathrm{~km}^{2}$ [21]. Small gas pockets (few meters horizontally) [22]
Chirp (40-60 and 40-80 kHz), Kongsberg EA400 echosounder ( $38 \mathrm{kHz}$ and $200 \mathrm{kHz})$, Odom MK III echosounder (12 kHz)
Kongsberg EA400 echosounder (38 kHz and $200 \mathrm{kHz}$ )

$38 \mathrm{kHz}$ echosounder (RV Baltica)

Air gun and horizontal line of 24 or 48 hydrophones

Chirp (40-60 and 40-80 kHz), Kongsberg EA400 echosounder (38 kHz and $200 \mathrm{kHz})$, Odom MK III echosounder (12 kHz)
Orłowski 2009; Majewski and Klusek 2014

Majewski 2014; Klusek and Majewski 2012; Majewski and Klusek 2011; Brodecka et al. 2013

Majewski and Klusek 2011; Brodecka et al. 2013

Orłowski 2009; Klusek and Majewski 2012

Klusek et al. 2010; Majewski and Klusek 2014

Majewski and Klusek 2011

Orłowski 2009

Domżalski et al. 2004; PIG-PIB et al. 2008

Majewski 2014; Majewski and Klusek 2011; Brodecka et al. 2013 
Table 2 (continued)

\begin{tabular}{|c|c|c|c|}
\hline Area & Finding & Equipment & Publication \\
\hline \multirow{4}{*}{ Bornholm Basin } & $\begin{array}{l}\text { Link between structural geological traps and } \\
\text { presence of acoustic manifestation of gas } \\
\text { presence } \sim 35.8 \mathrm{~km}^{2}[23]\end{array}$ & $\begin{array}{l}\text { Air gun with } 24 / 48 \text { horizontal array of hydro- } \\
\text { phones }\end{array}$ & $\begin{array}{l}\text { Domżalski et al. 2004; PIG-PIB } \\
\text { et al. } 2008\end{array}$ \\
\hline & $\begin{array}{l}\text { Acoustic flare (gas ebullition) caused by CTD } \\
\text { hitting the sea bottom [24] }\end{array}$ & 38-kHz echosounder (RV Baltica) & Orłowski 2009 \\
\hline & $\begin{array}{l}\text { Area of acoustic blanking (echosounder) and } \\
\text { layer enhancement (multibeam) } \sim 3 \mathrm{~km}^{2}- \\
\text { methane presence verified by core sampling } \\
\text { (close proximity to PEEZ-north) }\end{array}$ & $\begin{array}{l}\text { 10-kHz Innomar Parametric Sediment } \\
\text { Echosounder, 12-khZ multibeam }\end{array}$ & Jørgensen and Fossing 2012 \\
\hline & $\begin{array}{l}\text { Acoustic speed reduction on gaseous layers } \\
\text { (from } 1450 \text { to less than } 500 \mathrm{~m} \mathrm{~s}^{-1} \text { ). } \\
\text { Superiority of low-frequency methods in } \\
\text { sub-bottom methane detection (close prox- } \\
\text { imity to PEEZ-north) }\end{array}$ & $\begin{array}{l}\text { 10-kHz Innomar Parametric Sediment Echo } \\
\text { Sounder, } 12 \text { and } 95-\mathrm{khZ} \text { multibeam, } \\
\text { Parasound sediment echosounder }(4.2,18.5 \text {, } \\
\text { and } 42.8 \mathrm{kHz}) \text {, Gi-Gun } 200 \mathrm{~Hz}\end{array}$ & $\begin{array}{l}\text { Jørgensen and Fossing 2012; } \\
\text { Toth et al. 2014b }\end{array}$ \\
\hline Pomeranian Bight & $\begin{array}{l}\text { Structural gas trap above gas-bearing layer of } \\
\text { sediments (quartz sandstone from the Middle } \\
\text { Cambrian) - high potential for deep accu- } \\
\text { mulation of methane and petroleum hydro- } \\
\text { carbons [25] }\end{array}$ & $\begin{array}{l}\text { Air gun and horizontal line of } 24 \text { or } 48 \\
\text { hydrophones (during the 1970s and 1980s) }\end{array}$ & PIG-PIB et al. 2008 \\
\hline
\end{tabular}

linked to the variability in gaseous methane concentration profiles, as in the Eckernförde Bay (Albert et al. 1998). At some points, strong non-linear response of the seabed observed for the sum of prime frequencies (100 and $110 \mathrm{kHz}$ ) indicated the gas bubble presence. Based on a non-linear scattering model of bubbles, the estimated number of resonance bubbles reached values of $300 \mathrm{~m}^{-3} \mu \mathrm{m}^{-1}$ in the uppermost surface layer of sediments (Newhouse and Shankar 1984; Phelps et al. 1997; Tęgowski et al. 2003; Table 2). The highest concentrations of gas in sediments were estimated in this region for silty clay and the lowest for clay-silt and glacial clay, based on a non-linear method [5] (Jakacki et al. 2002). A specific characteristic of this southwestern region is the fact that acoustic blanking often occurs suddenly, without any other acoustic anomalies in sediments in close proximity [7] (Rudowski et al. 2010; Majewski and Klusek 2011; Majewski 2014). Acoustic anomalies of a similar nature were registered using a 12-kHz echosounder during measurements conducted from onboard R/V Oceania in November 2017 [1] by the authors of this article (Fig. 1a). Significant spatial variability in this region is also reflected in the average concentration of methane present in the first meter of sedimentsfrom approx. 0.25 to approx. $3 \mathrm{mmol} \mathrm{dm}^{-3}$ (Brodecka et al. 2013). High spatial variability may also be connected with the following: the geological complexity of the southwestern part of the Gulf of Gdańsk, high spatial variability of sediments, relatively low depth, temperature, and geochemical parameters (Uścinowicz 1995; PIG-PIB et al. 2008; Brodecka et al. 2013), as well as groundwater discharges (PiekarekJankowska 1994; Bussmann and Suess 1998; Matciak et al. 2015). Additionally, acoustic results from the Puck Bay (Fig. 3, south of the Hel Peninsula) obtained in different years may indicate the temporal variation of gas presence in sediments. Acoustic data collected in November 2017 indicate that the area of gas bubble presence in sediments (acoustic blanking) extends much further to the west than previously stated [1, 39] (Majewski 2014; Brodecka et al. 2013). Based on acoustic anomalies in seismic data and structural deformations, Rudowski et al. (2010) claimed that methane in this area [7] originates from shallow buried organic rich sediments from the period before littoral transgression and may also be connected with deep geological structures.

The largest gas-saturated region is located in the central part of the Gulf of Gdańsk [8, 9] $\left(54^{\circ} 35^{\prime}-54^{\circ} 40^{\prime} \mathrm{N}\right.$ and $18^{\circ}$ $50^{\prime}-19^{\circ} 20^{\prime}$ E; Fig. 3) and demonstrates numerous acoustic anomalies such as acoustic blanking, acoustic turbidity, stratification discontinuities, layer enhancement, and negative phase reflection. The central region includes areas of gas saturated sediments and gas pockets as well as active (with gas seeps) and inactive pockmarks [9, 10, 11] (Majewski 2014; Majewski and Klusek 2011; Brodecka et al. 2013; Majewski and Klusek 2014; Table 2). The time and rate of the gas seeps in this region were calculated by Orłowski [12] (2009; Table 2). Irregularity of gas seeps (2011-2017 measurement campaigns) may be connected with specific sub-vertical fractures in sediments, connected with gas presence (Best et al. 2006), which can be open or close in different periods in time therefore controlling seep activity. It was found that gaseous methane in this central region can be associated with acoustically soft sediments (low reflectivity and attenuation), such as hydrated mud and clays, which enable mapping of upper subsurface structures of sediments using higher frequencies [8, 9, 17] (e.g., $12 \mathrm{kHz}$, Majewski and Klusek 2011) than those found in typical low-frequency sub-bottom profiles. The use 
Fig. 3 Map presenting localization of selected results indicating shallow gas presence in sediments of the eastern part of the Polish EEZ (Gdańsk Basin, Gotland Basin, Stilo Bank). Results from the numbered areas are discussed in more depth in sub-chapters with the corresponding geographical area names (Fig. 1) and marked as [no.]

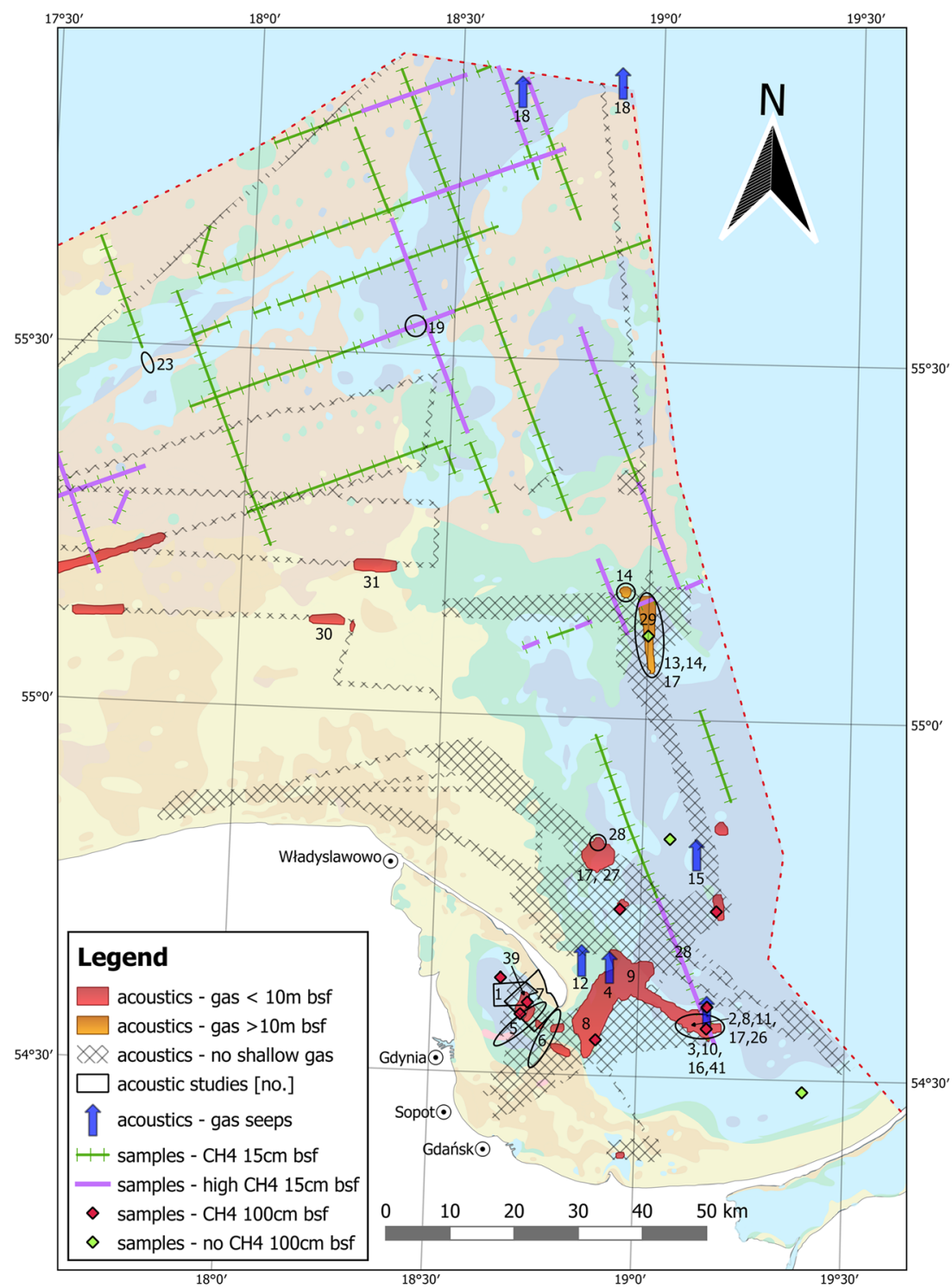

of higher frequencies gives higher sub-bottom resolution and reveals stronger acoustic anomalies in imaging, caused by gas presence (Anderson and Hampton 1980; Abegg and Anderson 1977). Gas manifestations observed in the $12-\mathrm{kHz}$ (and also 38-kHz) data set collected in the central part of the Gulf of Gdańsk are related to acoustic blanking (high attenuation), layer enhancement (strong volume scattering), and acoustic turbidity [17] (Majewski and Klusek 2011). The geochemical sediment sampling carried out by PIG-PIB et al. (2008) indicated the presence of gas in sediments located much further to the north than was reported by acoustic measurements conducted several years later [28] (Fig. 3).

In the central Gulf of Gdańsk, there are also geomorphological structures classified as pockmarks. These are grouped together in larger areas and located in close proximity to each other [11] (Fig. 3). The active pockmarks [11] (54 $34^{\circ} \mathrm{N}$ N $19^{\circ}$ $10^{\prime}$ E; Fig. 3) are present in the eastern part of the highly saturated area of sediment [9] $\left(54^{\circ} 35^{\prime}-54^{\circ} 40^{\prime} \mathrm{N}\right.$ and $18^{\circ}$ $50^{\prime}-19^{\circ} 20^{\prime}$ E; Fig. 3). The SMTZ layer in sediments from the central part of the Gulf of Gdańsk, where acoustic measurements indicated the presence of gaseous methane, was located at depths of approx. 8-15 cm bsf (station in central part) and $18-55 \mathrm{~cm}$ bsf (station located more to the north) (Brodecka 2013). Orłowski (2009) observed gas seepage due to the abundance of gas in very shallow sediments in that region $[12,15,16]$. In the years 2014-2018, during numerous $12-\mathrm{kHz}$ measurement campaigns from aboard the R/V Oceania (IO PAS), the changeable nature and activity of pockmarks were observed in that area $[2,3,11]$ (unpublished data). The single largest structure with gas seeps was observed acoustically (side-scan sonar) by Majewski (2014) and was estimated to have a width of $300 \mathrm{~m}$ [2] (Fig. 2b). That active pockmark was located in acoustically soft, highly hydrated (water content $>80 \%$ in the first $80 \mathrm{~cm}$ ) muddy sediments 


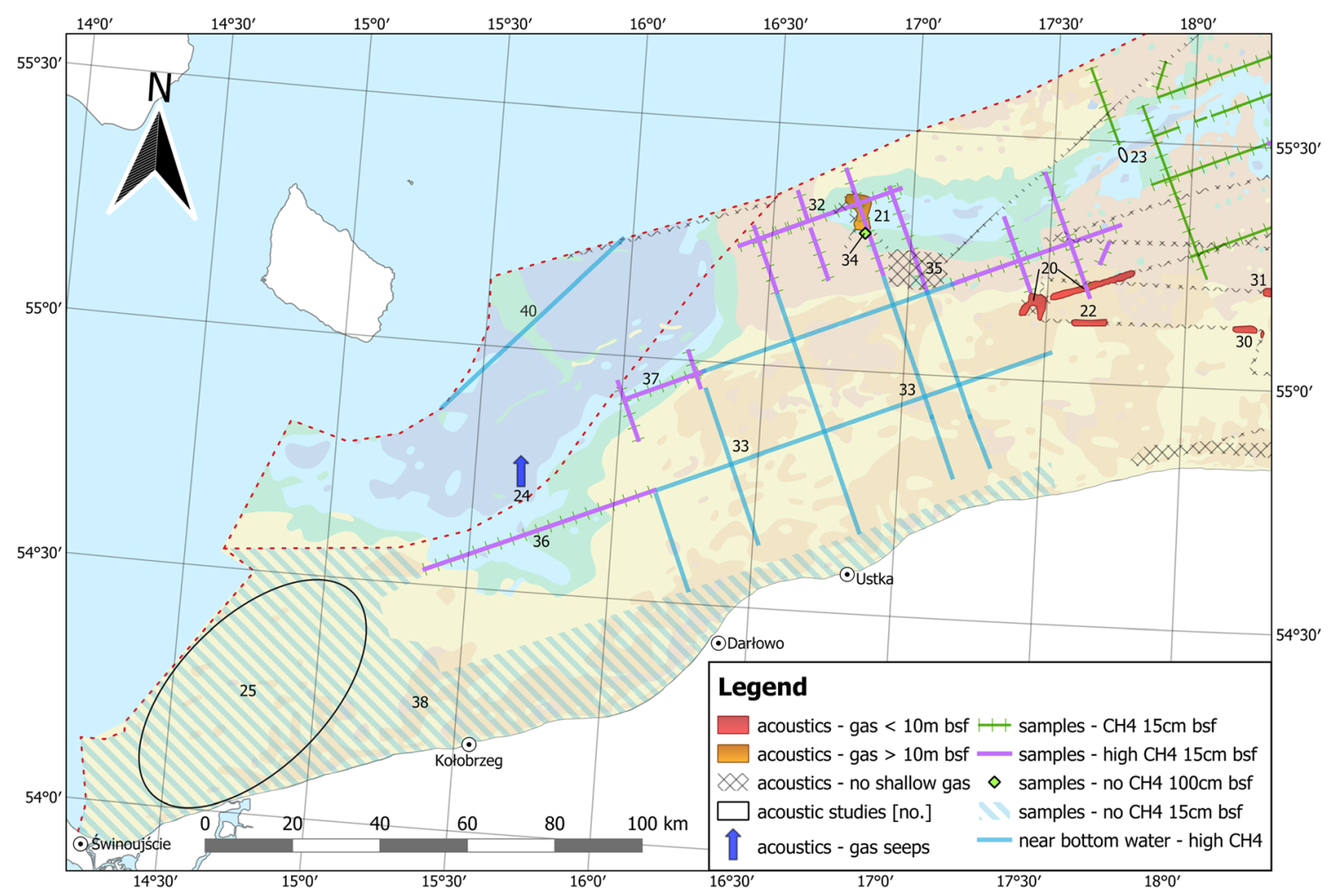

Fig. 4 Map presenting the localization of selected results indicating shallow gas presence in sediments of the western part of the Polish EEZ (Słupsk Furrow, Słupsk Bank, Bronholm Basin, Odra Bank, Pomeranian
Bight). Results from numbered areas are discussed in more depth in the sub-chapters with corresponding geographic area name (Fig.1) and marked as [no.]
(Mojski 1995; Brodecka et al. 2013) in the region of a fault zone (based on boomer and $12-\mathrm{kHz}$ data) (Majewski and Klusek 2011). Pockmark structures in that area are usually characterized by disorderly layering of sub-bottom stratification, probably due to the displacement of gas bubbles in sediment structures, strong signal enhancement from its surface, and strong acoustic blanking of underlying layers (Majewski and Klusek 2011, 2014).

In the northern and northwestern parts of the Gulf of Gdańsk, numerous smaller (compared to those in the central part) and scattered patches of gas-saturated sediments [27] were located and these also included pockmark structures [28] (18 50'-19 $15^{\circ}$ E, Fig. 3) (Majewski 2014; Brodecka et al. 2013; Majewski and Klusek 2014).

\section{Gdańsk Deep and Gotland Basin}

In the central part of the Gdańsk Deep $\left(55^{\circ} 10^{\prime} \mathrm{N} 19^{\circ} 00^{\prime} \mathrm{E}\right)$, large inactive pockmarks buried at depths of a few meters bsf were discovered by acoustic methods [14] (Majewski and Klusek 2011). Gas-bearing sediments and buried pockmarks of up to $300 \mathrm{~m}$ in diameter were first found and described by a Polish-Soviet geological expedition in the late 1980s, in the deepest part of the eastern Gdańsk Basin, situated in muddy sediments (Geodekyian et al. 1990). Geochemical sampling conducted by PIG-PIB et al. (2008) showed significant amounts of methane in the uppermost layer of sediments in that area (Fig. 3). However, geochemical analyses of the short cores $(50 \mathrm{~cm})$ collected in the central part of one of the buried pockmarks, carried out in 2010-2011, showed no signs of the SMTZ and only trace amounts of methane (on average < $0.1 \mathrm{mmol} \mathrm{dm}^{-3}$ ) (Brodecka et al. 2013). The periodic appearance of vertical gas migration events originating in deeper layers may serve to explain the discrepancies between the abovementioned geochemical results [29] (Brodecka 2013; PIG-PIB et al. 2008). Moreover, gas craters with gas chimneys were also acoustically observed in the area of the Gdańsk Deep [13, 14] (Majewski and Klusek 2011), although geochemical profiles were not long enough (only $1 \mathrm{~m}$ ) to fully describe changes in methane concentrations (Brodecka 2013).

According to the report issued by PIG-PIB et al. (2008), methane may be present in the upper $20 \mathrm{~cm}$ of sediments in numerous locations of the Gdańsk Deep; however, due to relatively low concentrations, it is not always observed with acoustic methods. Moreover, numerous fault zones and displacements at depths of 30 to $100 \mathrm{~m} \mathrm{bsf}$ in the area of the Gdańsk Deep may lead to the presence of gaseous methane and higher hydrocarbons in shallower sediments (Domżalski et al. 2004; PIG-PIB et al. 2008) due to migration from deeper layers.

Additionally, two smaller regions with acoustic anomalies typical of gas-saturated sediments have been registered in the 
region of Stilo Bank, situated north of the seaside town of Władyslawowo, at $55^{\circ} 10^{\prime} \mathrm{N} 18^{\circ} 20^{\prime} \mathrm{E}[30,31]$ (Majewski and Klusek 2011). Unfortunately, sediments from that area were not geochemically analyzed for methane presence.

In the Gotland Basin, two acoustic flares were observed as a result of gas ebullition caused by the impact of a CTD probe on the seafloor [18] (Orłowski 2009). High concentrations of methane in sediments (up to $28 \mathrm{~cm}^{3} \mathrm{~kg}^{-1}$ ) support the hypothesis that small disturbances on the seafloor may lead to events such as gas ebullition or small gas seep (PIG-PIB et al. 2008). In the southern part of the Gotland Basin, several gas diffusion chimneys and one 1.4-km-wide gas crater, with characteristic acoustic blanking of sub-bottom layers, were reported based on seismo-acoustic results [19] (Domżalski et al. 2004). The part of the Gotland Basin where the sub-bottom gas crater was discovered [19] is characterized by a methane concentration two orders of magnitude lower in the sediments than that in locations with gas ebullition [18] (PIG-PIB et al. 2008).

An increase of about $2{ }^{\circ} \mathrm{C}$ in the temperature of bottom seawater in relation to previous years is considered to be a factor influencing the number of observed gas seeps in the Polish EEZ (Orłowski 2009). Gas seeps linked to temperature rise were observed in two locations north of the Gdańsk Deep $[15,16]$ (approx. $55^{\circ} 50^{\prime} \mathrm{N} 18^{\circ} 40^{\prime} \mathrm{E}$ ) and the Bornholm Deep [24] (approx. 54 43' N 15 40' E) (Orłowski 2009; Table 2). Some more examples of seasonal acoustic gas front variations can be found in the literature (Eckernforde Bay sediments: Wever and Fiedler 1995; Wever et al. 1998). They are mostly correlated with the temperature cycle of the atmosphere, although local variations in sedimentary methane profiles may also be attributed to groundwater seepage (Bussmann and Suess 1998).

Multidimensional echosignal parametrization, used for sediment classification in the southern Baltic Sea region (Tęgowski 2002, 2005, Tęgowski and Zieliński 2006; Walree et al. 2005), turned out to enable the separation of the gas pockmark region from the non-gaseous sediments [17] (Majewski and Klusek 2014). The signal analysis performed by Majewski and Klusek (2014) for the area of active

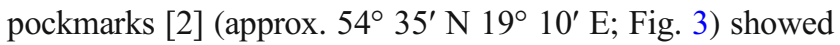
some differences between the wavelet decomposition parameters of echo time series in gaseous structures, and in sediments without or with only a small amount of gas (Table 2). The most conspicuous differences were observed between active pockmarks [2] and sediments with lower methane saturation than pockmarks $[6,8]$, at all of the used frequencies (i.e., 70, 120, $200 \mathrm{kHz}$ ), for echo features such as entropy, second-order moment, zero-order moment, and skewness as a measure of envelope asymmetry.

The echo parametrization applied in the search for saturated sediments also returned promising results (Majewski and Klusek 2014), both at lower (12 kHz) and higher frequencies $(70,120,200 \mathrm{kHz})$. The wavelet transformed $12-\mathrm{kHz}$ data revealed very high sensitivity to signal penetration alterations (Majewski 2014), which are strongly associated with gas presence in sediments $[6,8,17]$ (Table 2). Gas-saturated sediments also exhibited very strong changes of zero-order moment, second-order moment, and skewness for $12-\mathrm{kHz}$ signals, and less pronounced but nevertheless significant changes for 70 , 120 , and $200 \mathrm{kHz}$ (Majewski 2014). Automatic and objective discrimination between gassy [17] and gas-free sediments can be obtained using classification algorithms based on the extraction of echo energy parameters via wavelet transformation (or with Shannon entropy of the wavelet transform coefficients but with poorer results) for 70-, 120-, and 200-kHz data [17]. In such instances, lower variation dynamics among the parameters may be regarded as a worthy indicator of lower content of gas bubbles (Majewski and Klusek 2014).

\section{Słupsk Furrow, Słupsk Bank, and Bornholm Basin}

Acoustic measurements carried out with the use of $38-\mathrm{kHz}$ and $40-60-\mathrm{kHz}$ echosounders indicated sites of deep gas presence in the Słupsk Furrow at about $10 \mathrm{~m}$ bsf [21] (Majewski and Klusek 2011) (Fig. 4, orange polygon). However, during campaigns in 2010-2011, a very hard bottom in the core sampling area made it impossible to collect sediment cores longer than $40 \mathrm{~cm}$ (methane concentrations in those cores were < $0.01 \mathrm{mmol} \mathrm{dm}^{-3}$ ), and probably also prevented methane migration from deeper layers to the surface (Table 2). Interestingly, in some areas of the Słupsk Furrow close to the site mentioned above, methane concentrations in the surface sediment layer of $20 \mathrm{~cm}$, which were measured during PIG-PIB campaigns (PIG-PIB et al. 2008), were exceptionally high [32] (up to $19 \mathrm{~cm}^{3} \mathrm{~kg}^{-1}$ of sediment) in comparison with the other regions of the Polish EEZ (PIG-PIB et al. 2008). Concentrations of dissolved methane measured in the nearbottom water of that area were also high [33] and some part of the region was assessed as having high potential for methane occurrence [36, 37] (PIG-PIB et al. 2008). Very high concentrations ( $>160 \mathrm{nmol} \mathrm{dm}^{-3}$ ) of methane dissolved in water were reported at depths exceeding $100 \mathrm{~m}$, in the area within the Słupsk Furrow (Schmale et al. 2010). In general, there are some discrepancies between the results of methane occurrence at specific sites in the Słupsk Furrow and on the Słupsk Bank, obtained during PIG-PIB campaigns carried out in 20052007, and those obtained in 2010-2014 by Brodecka et al. [34] (2013) and Majewski (2014). For example, a high amount of methane measured by PIG-PIB et al. (2008) in sediment from the area of the gray net mask intersected with purple profile (Fig. 4; [35]) did not match up with any acoustic anomalies connected with gas bubble presence in that area (Majewski 2014).

Shallow gas-bearing sediments were also acoustically observed in the Słupsk Furrow/Bank area, e.g., at $55^{\circ} 10^{\prime} \mathrm{N} 17^{\circ}$ $25^{\prime}-17^{\circ} 50^{\prime}$ E [20] (Majewski 2014; Brodecka et al. 2013) as 
well as small gas pockmarks [22] (12 kHz and $38 \mathrm{kHz})$. This information may suggest that it is possible for gas seeps to occur in that region. However, none of them were observed in the form of acoustic flares during a dedicated measuring campaign $(200 \mathrm{kHz})$ carried out in the most promising area (Majewski and Klusek 2011). In turn, gas outflows were noted in close proximity to the Bornholm Deep by Orłowski [24] (2009), in the area which had previously demonstrated high methane concentrations in sediments in relation to other areas (up to $0.1 \mathrm{~cm}^{3} \mathrm{~kg}^{-1}$ ) during PIG-PIB campaigns [36, 37] (PIG-PIB et al. 2008).

The southeastern part of the Bornholm Basin had concentrations of dissolved methane around $8-12 \mathrm{nmol} \mathrm{dm}^{-3}$ in its near-bottom waters $(80 \mathrm{~m})$ [40] (without corresponding acoustic studies), which were lower than those in the western part (up to $40 \mathrm{nmol} \mathrm{dm}{ }^{-3}$ ), located further from the PEEZ (Schmale et al. 2010). There was an unexpected situation in the eastern part of the Bornholm Basin as methane concentrations did not increase with depth and oxygen depletion and the maximum concentration was $20 \mathrm{~m}$ above the seafloor (Schmale et al. 2010). This anomaly is possibly connected to more intense near-bottom water circulation in this region. Such conditions can also be linked to the presumably lower amount of gas in sediments. In the southern Bornholm Basin, acoustic flares connected with gas seeps were observed when a CTD probe impacted upon the floor [24] (Orłowski 2009). In the northern Bornholm Basin, strong acoustic manifestations of gas presence were observed, but outside the PEEZ (Jørgensen and Fossing 2012; Toth et al. 2014b).

\section{Pomeranian Bight and Odra Bank}

The western part of the Polish EEZ, which is located close to gas-petroleum structures on land, has been assessed as being a prospective search site for hydrocarbon [25] (highest prospectivity in the Pomeranian Bight), especially these of petroleum type. This may suggest methane presence in that area (PIG-PIB et al. 2008). Acoustic data from that region include 23 seismic profiles (approx. $15^{\circ} 20^{\prime} \mathrm{E}$ to the west of Kołobrzeg) collected during the 1970s and 1980s by PIG-PIB and complemented by detailed geochemical studies (bluestriped area [38]) carried out in 2006 (PIG-PIB et al. 2008). The seismic data were collected using an air gun and a horizontal line of 24 or 48 hydrophones (Table 2). They indicated potentially deep accumulation of methane, based on structures of geological traps located 30-60 $\mathrm{m}$ above the formations generally associated with high gas and petroleum (quartz sandstones of the Middle Cambrian), in all of the area to the west of $16^{\circ} 00^{\prime} \mathrm{E}$ [25].

Unfortunately, there are no results from higher frequencies for that region [38]. Geochemical studies conducted in 2006 showed no traces of methane in the uppermost $2 \mathrm{~cm}$ of sediments (PIG-PIB et al. 2008). Significant amounts of this gas (above $0.3 \mathrm{~cm}^{3} \mathrm{~kg}^{-1}$ ) were only found to be present in the surface layer of sediments to the east of $15^{\circ} 20^{\prime} \mathrm{E}$ and north of 54 $30^{\prime} \mathrm{E}$ (near the Bornholm Basin [36] and in the direction of the Slupsk Furrow [37]). Dissolved methane was found in the near-bottom water of that region, in concentrations ranging from a dozen to a hundred micromoles per cubic decimeter [38].

\section{Summary}

Acoustic studies on shallow gas in surface sediments, having been conducted in the Polish EEZ since the early 1990s, have been based on the application of a wide variety of acoustic devices and methods (Table 2). The eastern part of the Polish EEZ has been studied significantly more often in terms of shallow gas than the western part. The areas of the Polish EEZ in which shallow gas has been most frequently registered include the Gdańsk Basin and the Stupsk Furrow. The Gulf of Gdańsk (part of the Gdańsk Basin) has been of main interest in the investigations of methane occurrence, due to specific environmental conditions in that area. These conditions, i.e., proximity to land and to the estuary of the main Polish river, the Vistula, as well as high primary production and sedimentation rate, create a suitable background for methanogenesis in shallow sediments. Thus, methane concentrations at some sites in that area reach values of as much as $7 \mathrm{mmol} \mathrm{dm}^{-3}$ in the $50-\mathrm{cm}$ surface sediment layer, and the SMTZ is generally located at sediment depths shallower than $1 \mathrm{~m}$. The Słupsk Furrow has fewer reported observations of shallow gas in sediments. This could be a result of the lower number of acoustic surveys undertaken here as opposed to the Gdańsk Basin area (statistical aspect), and the periodical inflows of heavier (higher PSU), oxygen-rich water which significantly change geochemical conditions near the bottom (environmental aspect). The acoustic and geochemical research projects carried out in the western part of the PEEZ (Pomeranian Bight and Odra Bank) were mainly focused on the assessment of the potential for petroleum industry exploration. Interestingly, at most stations in that region, methane was not found in surface sediments despite its significant amounts in the near-bottom water (a dozen to a hundred $\mu \mathrm{mol} \mathrm{dm}{ }^{-3}$ ). Generally, the PEEZ part of the Bornholm Basin has lack of data regarding shallow gas.

The most common acoustic manifestations of gas presence in sediments within the PEEZ are acoustic blanking (3), layer enhancement (2), acoustic turbidity (1), and also strong acoustic energy attenuation in pockmark structures (8). There are significant differences in terms of how gas displays in acoustic records, even over relatively close areas (e.g., western and central Gulf of Gdańsk). For example, in the western part of the Gulf of Gdańsk, regular, widespread, and homogeneous expressions of shallow gas were observed [7] (Fig. 2a). In 
contrast in the central part [11], they were more irregular and spatially limited but also significantly stronger (Fig. 2e). In the western part of the Gulf of Gdańsk, there are numerous inactive pockmarks [17]; however, there is an active pockmark of considerable size [10] located in the central part of the Gulf of Gdańsk (Fig. 2b). Another group of several buried inactive pockmarks is located in the northern part of the Gdańsk Deep [14], suggesting greater age [27]. There are several scattered areas within the central part of the PEEZ with gassaturated sediments, characterized mainly by acoustic blanking and acoustic turbidity [20,21,22]. On the whole, there is a shortage of acoustic studies in the western part of the PEEZ, except for seismic studies conducted by PIB-PIG which are focused on deeper strata of sediments. Nevertheless, some very detailed and far-reaching geochemical studies, indicating the presence of methane in near-bottom waters and sediments, were conducted in this region [38]. Unfortunately, though, in this area, there is a general lack of information about its presence in gaseous form in the uppermost sediments ( $1 \mathrm{~m} \mathrm{bsf}$ ).

It is suggested that, in the Gdańsk Basin region, shallow gaseous sediments are subjected to significant variations with time. This hypothesis is based on synthesis of information from multiple articles supported not only by acoustic surveys, conducted over many years (10-year period) in the region of the Gdańsk Basin (Fig. 2), but also by complementary geochemical studies (at the same locations). The main time changes include methane concentration in the sediment profile, slightly altered spatial range of gaseous sediment occurrence (based on acoustic data), and most significantly, the activity of pockmarks.

The performed acoustic studies indicate the presence of over $700 \mathrm{~km}^{2}$ of gaseous sediments in the PEEZ, with many potential areas still to be surveyed (central and western PEEZ). Acoustic methods are shown to have significant informative value on gaseous methane occurrence, as verified by geochemical studies. In the eastern part, a great extent of gaseous sediments was discovered together with results showing their distinct nature. The central PEEZ has multiple scattered areas of saturated sediments, with intensification of their presence toward the Słupsk Furrow. The western part of the PEEZ has been structurally (seismic studies) and geochemically assessed as a region with potential for gas occurrence at deeper sediment depths (above a few meters).

Funding information The study was supported by the National Science Center, Poland, project no. UMO-2016/21/B/ST10/02369.

Open Access This article is distributed under the terms of the Creative Commons Attribution 4.0 International License (http:// creativecommons.org/licenses/by/4.0/), which permits unrestricted use, distribution, and reproduction in any medium, provided you give appropriate credit to the original author(s) and the source, provide a link to the Creative Commons license, and indicate if changes were made.
Publisher's Note Springer Nature remains neutral with regard to jurisdictional claims in published maps and institutional affiliations.

\section{References}

Abegg F, Anderson AL (1977) The acoustic turbid layer in muddy sediments of Eckernförde Bay, Western Baltic Sea: methane concentration, saturation and bubble characteristics. Marine Geology 137: $137-147$

Albert DB, Martens CS, Alperin MJ (1998) Biogeochemical processes controlling methane in gassy coastal sediments - Part 2: groundwater flow control of acoustic turbidity in Eckernförde Bay Sediments. Cont Shelf Res 18(14-15):1771-1793

Anderson AL, Hampton LD (1980) Acoustics of gas-bearing sediments. JASA 67(6):1865-1903. https://doi.org/10.1121/1.384453

Anderson AL, Abegg F, Hawkins JA, Duncan ME, Lyons AP (1998) Bubble populations and acoustic interaction with the gassy floor of Eckernförde Bay. Cont Shelf Res 18(14-15):1807-1838

Baltzer A, Tessier B, Nouze H, Bates R, Moore C, Menier D (2005) Seistec Seismic Profiles: A Tool to Differentiate Gas Signatures. Mar Geophys Res 26(2-4):235-245

Bange H, Bartell U, Rapsomanikis S, Andreae MO (1994) Methane in the Baltic and North Seas and a reassessment of the marine emissions of methane. Glob Biogeochem Cycles 86:465-480

Bange H, Bartell U, Rapsomanikis S, Anreae MO (1996) Nitrous oxide emissions from the Arabian Sea. Geophys Res Lett 23(22):31753178

Barnes RO, Goldberg ED (1976) Methane production and consumption in anoxic marine sediments. Geology 4(5):297-300. https://doi.org/ 10.1130/0091-7613(1976)4<297:MPACIA>2.0.CO;2

Best AI, Tuffin MDJ, Dix JK, Bull JM (2004) Tidal height and frequency dependence of acoustic velocity and attenuation in shallow gassy marine sediments. J. Geophys. Res. 109(B8):B08101. https://doi. org/10.1029/2003JB002748

Best AI, Richardson MD, Boudreau BP et al (2006) Shallow seabed methane gas could pose coastal hazard. Eos 87(22):213-215

Boudreau BP, Algar C, Johnson BD et al (2005) Bubble growth andrise in soft sediments. Geology 33(6):517-520. https://doi.org/10.1130/ G21259.1

Boyle FA, Chotiros NP (1998) Nonlinear acoustic scattering from a gassy poroelastic seabed. JASA 103(3):1328-1336

Breas O, Guillou C, Reniero F, Wada E (2001) The global methane cycle: isotopes and mixing ratios, sources and sinks. Isot Environ Health Stud 37:257-379

Brink KH, Robinson AR (2005) Global coastal ocean: regional studies and syntheses. Harvard University Press, Cambridge

Brodecka AM (2013) Factors controlling methane occurrence in sediments of the Southern Baltic (in Polish). Dissertation, University of Gdańsk

Brodecka A, Majewski P, Bolałek J, Klusek Z (2013) Geochemical and acoustic evidence of methane in sediments of the Polish sector of the southern Baltic Sea. Oceanologia 55(4):951-978

Bussmann I, Suess E (1998) Groundwater seepage in Eckernförde Bay (Western Baltic Sea): effect on methane and salinity distribution of the water column. Cont Shelf Res 18(14-15):1795-1806. https:// doi.org/10.1016/S0278-4343(98)00058-2

Bussmann I, Dando P, Niven S, Suess E (1999) Groundwater seepage in the marine environment: Role for mass flux and bacterial activity. Mar Ecol Prog Ser 178:169-177

Chu D (1997) High-frequency bistatic scattering by sub-bottom gas bubbles. JASA 102:806. https://doi.org/10.1121/1.419906

Claypool GE, Kaplan IR (1974) The origin and distribution of methane in marine sediments. In: Kaplan IR (ed) Natural gases in marine sediments. Plenum Press, New York, pp 99-139 
Claypool GE, Kvenvolden KA (1983) Methane and other hydrocarbon gases in marine sediment. Annu Rev Earth Planet Sci 11:299-327. https://doi.org/10.1146/annurev.ea.11.050183.001503

Davis AM (1992) Shallow gas: an overview. Cont Shelf Res 12(10): 1077-1079. https://doi.org/10.1016/0278-4343(92)90069-V

Diez R, García-Gil S, Duran R, Vilas F (2007) Gas accumulations and their association with particle size distribution patterns in the Ria de Arousa seabed (Galicia, NW Spain): an application of discriminant analysis. Geo-Mar Lett 27(2-4):89-102

Domżalski J, Górecki W, Mazurek A, Myśko A, Strzetelski W, Szamałek K (2004) The prospects for petroleum exploration in the eastern sector of Southern Baltic as revealed by sea bottom geochemical survey correlated with seismic data. Przegląd Geologiczny 52(8/2):792-799

Duarte H, Menezes Pinheiro L, Teixeira FA, Monteiro JH (2007) Highresolution seismic imaging of gas accumulations and seepage in the sediments of the Ria de Aveiro barrier lagoon (Portugal). Geo-Mar Lett 27:115-126. https://doi.org/10.1007/s00367-007-0069-z

Edgerton HE, Siebold E, Vollbrecht K, Werner F (1966) Sedimentation und Abrasion am Mittelgrund (Eckernförder Bucht, westliche Ostsee). Geologisches Institut der Christian-Albrechts-Universität Kiel 17:101-110. https://doi.org/10.2312/meyniana.1967.17.101

Emelyanov E (2002) Geology of the Gdańsk Basin, Baltic Sea. Yantarny skaz, Kaliningrad, p 494

Fleischer PT, Orsi H, Richardson MD, Anderson AL (2001) Distribution of free gas in marine sediments: A global overview. Geo-Mar Lett $21: 103-122$

Floodgate GD, Judd AG (1992) The origins of shallow gas. Cont Shelf Res 12:1145-1156

Garcia-Gil S, de Blas E, Martinez-Carreno N, Iglesias J, Rial-Otero R, Simal-Gandara J, Judd AG (2011) Characterisation and preliminary quantification of the methane reservoir in a coastal sedimentary source: San Simon Bay, Ria de Vigo, NW Spain. Estuarine Coastal Shelf Sci 91(2):232-242

Garcia-Gil S, Vilas F, Garcia-Garcia A (2002) Shallow gas features in incised-valley fills (Ria de Vigo, NW Spain): a case study. Cont Shelf Res 22(16):2303-2315. https://doi.org/10.1016/S02784343(02)00057-2

Gardner TN, Sills GC (2001) An examination of the parameters that govern the acoustic behavior of sea bed sediments containing gas bubbles. JASA 110:1878-1889

Geodekyian AA, Trotsiuk VY, Blazhchishin AI (1990) Geoacoustic and gasometric and lithogeochemical investigations in the Baltic Sea (in Russian) Moscow

Greinert J, Artemov Y, Egorov V, De Batist M (2006) Daniel McGinnis, 1300 -m-high rising bubbles from mud volcanoes at $2080 \mathrm{~m}$ in the Black Sea: Hydroacoustic characteristics and temporal variability. Earth Planet Sci Lett 244(1-2):1-15. https://doi.org/10.1016/j.epsl. 2006.02.011

Grunwald M, Dellwig O, Beck M, Dippner JW, Freund JA, Kohlmeier C, Schnetger B, Brumsack HJ (2009) Methane in the southern North Sea: Sources, spatial distribution and budgets. Estuar Coast Shelf Sci 81(4):445-456

Gülzow W, Gräwe U, Kedzior S, Schmale O, Rehder G (2014) Seasonal variation of methane in the water column of Arkona and Bornholm Basin, western Baltic Sea. J Mar Syst 139:332-347

Hansson M, Andersson L, Axe P, (2011) Areal extent and volume of anoxia and hypoxia in the Baltic Sea 1960-2011. Rep. Oceanography 42

Hovland M, Judd AG, Burke RA (1993) The global flux of methane froma shallow subrmarine sediments. Chemosphere 26(1):559 578. https://doi.org/10.1016/0045-6535(93)90442-8

Huang B, Xiao X, Li X, Cai D (2009) Spatial distribution and geochemistry of the nearshore gas seepages and their implications to natural gas migration in the Yinggehai Basin, offshore South China Sea.
Mar Pet Geol 26(6):928:935. https://doi.org/10.1016/j.marpetgeo. 2008.04.009

Iglesias J, García-Gil S (2007) High-resolution mapping of shallow gas accumulations and gas seeps in San Simón Bay (Ría de Vigo, NW Spain). Some quantitative data. Geo-Mar Lett 27(2-4):103-114. https://doi.org/10.1007/s00367-007-0065-3

Iversen N, Jorgensen BB (1985) Anaerobic methane oxidation rates at the sulfate-methane transition in marine sediments from Kattegat and Skagerrak (Denmark). Limnol Oceanogr 30(5):944-955

Jackson DR (1987) APL-UW third report of TTCP bottom scattering measurements: model development. APL-UW Rep. 8708, APLUniversity of Washington, Seattle

Jackson DR, Richardson M (2007) High-frequency seafloor acoustics. Springer-Verlag, New York

Jakacki J, Klusek Z, Tęgowski J (2002) The non-linear method of gas bubbles detection in the bottom sediments. Revista de Acustica 33

Jankowska H (1993) The bottom deposits of Puck Bay. Stud Mat Oceanogr 64:163-171. (in Polish).

Jones AT, Greinert J, Bowden DA, Klaucke I, Petersen CJ, Netzeband GL, Weinrebe W (2010) Acoustic and visual characterisation of methane-rich seabed seeps at Omakere Ridge on the Hikurangi Margin, New Zealand. Mar Geol 272(1):154:169. https://doi.org/ 10.1016/j.margeo.2009.03.008

Jørgensen BB, Fossing H (2012) Methane gas and seismo-acoustic mapping. In: Jørgensen BB, Fossing H (ed) Baltic Gas final scientific report. pp 8-12

Judd AG (2000) Geological sources of methane. In: Khalil MAK (ed) Atmospheric methane: its role in the global environment. Springer, Berlin, Heidelberg, pp 280-303

Kiene RP (1991) Production and consumption of methane in aquatic systems, microbial production and consumption of greenhouse gases: methane, nitrogen oxides, and halomethanes. In: JE Rogers, WB Whitman (eds) Am. Soc. Microbiol., Washington, pp 298

Klusek Z, Majewski P (2012) Rising of methane gas bubbles through the water column and pockmark distribution in the Gdansk Basin. In: BB Jørgensen, H Fossing (eds) Baltic Gas final scientific report, pp $13-15$

Klusek Z, Śliwiński A, Tęgowski J, Groza K (1993) Sea bottom examinations by backscattering of ultrasonic signals in the Southern Baltic Sea. Ultrasonic International 93 Conference Proceedings, pp 599602

Klusek Z, Matwiejew AL, Potapow AI, Sutin AM (1995) Observation of non-linear scattering of acoustical waves at sea sediments. Acoustic Letters 18(11):198-203

Klusek Z, Majewski P, Dragan A (2010) CW and chirp shallow sea bottom backscattering experiments. Hydroacoustics 13:135-142

Kostecki R, Janczak-Kostecka B (2012) Holocene environmental changes in the south-western Baltic Sea reflected by the geochemical data and diatoms of the sediment cores. Journal of Marine System 105108. https://doi.org/10.1016/j.jmarsys.2012.06.005

Kowalik PJ (2016) Water management in the Vistula delta (Poland). Meteorol Hydrol Water Manage 4(1):47-52. https://doi.org/10. $26491 / \mathrm{mhwm} / 63004$

Kvenvolden KA, Lorenson TD, Reeburgh WS (2001) Attention turns to naturally occurring methane seepage. Eos Trans AGU 82(40):457457

Laier T, Jensen JB (2007) Shallow gas depth-contour map of the Skagerrak-western Baltic Sea region. Geo-Mar Lett 27:127-141

Lee GH, Kim HJ, Kim DC, Yi BY, Nam SM, Khim BK, Lim MS (2008) The acoustic diversity of the seabed based on the similarity index computed from Chirp seismic data. ICES J Mar Sci 66(2):227-236

Łysiak-Pastuszak E, Drgas N (2004) Oxygen and hydrogen sulphide. In: Krzyminski M, Miętus Ł-PE (eds) Environmental conditions in the Polish zone of the Southern Baltic Sea during (in Polish). WInst. Meteorol. Water Manag., Gdynia 
Majewski W (2013) Sustainable development of the lower Vistula. Meteorol Hydrol Water Manage 1(1):33-38. https://doi.org/10. $26491 / \mathrm{mhwm} / 21814$

Majewski P (2014) Acoustic recognition of gas-bearing sediments in South Baltic (original in Polish: Akustyczne rozpoznanie form występowania gazonośnych osadów w Bałtyku Południowym). Dissertation, Institute of Oceanology of the Polish Academy of Sciences

Majewski P, Klusek Z (2011) Expressions of shallow gas in the Gdańsk Basin Majewski. Zeszyty naukowe Akademii Marynarki Wojennej 4(187):61-71

Majewski P, Klusek Z (2014) Parametters of echo signals originated from a gas seepage site in the southern Baltic Sea. Hydroacoustics 17: $143-150$

Martens CS (1999) Stable isotope tracing of anaerobic methane oxidation in the gassy sediments of Eckernfoerde Bay, German Baltic Sea. Am J Sci 299 (7-9):589-610

Matciak M, Bieleninik S, Botur A, Podgórski M, Trzcińska K, Dragańska K, Jaśniewicz D, Kurszewska A, Wenta M (2015) Observations of presumable groundwater seepage occurrence in Puck Bay (the Baltic Sea). Oceanol Hydrobiol Stud 44(2):267-272. https://doi. org/10.1515/ohs-2015-0025

Mathys M, Thießen O, Theilen F (2005) Seismic characterisation of gasrich near surface sediments in the Arkona Basin, Baltic Sea. GeoMar Lett 26(2):207-224. https://doi.org/10.1007/s11001-005-37194

Mojski JE (1995) In: Mojski JE (ed) Geological Map of the Baltic Sea bottom 1:200 000. Polish Geological Institute, Warszawa, pp 19881995

Mojski JE, Dadlez R, Słowanska B, Uścinowicz S, Zachowicz J (1995) Geological atlas of the southern Baltic, 1:500000. Pol. Geol. Inst., Sopot-Warszawa, pp 1-63. (in Polish)

Newhouse CL, Shankar PM (1984) Bubble sizing using the non-linear mixing of two frequencies. JASA 75(5):1473-1477. https://doi.org/ $10.1121 / 1.390863$

Orange D, García-García A, Lorenson T, Nittrouer C, Milligan T, Miserocchi S, Langone L, Correggiari A, Trincardi F (2005) Shallow gas and flood deposition on the Po Delta. Mar Geol 222 223:159-177

Orłowski A (2009) Acoustic Tracking Dynamic Phenomena in Marine Ecosystem. Hydroacoustics 12:167-180

Park SC, Yoo DG, Lee KW, Lee HH (1999) Accumulation of recent muds associated with coastal circulations, southeastern Korea Sea (Korea Strait). Cont Shelf Res 19:589-608

Pimenov NV, Ulyanova MO, Kanapatsky TA, Veslopolova EF, Sigalevich PA, Sivkov VV (2010) Microbially mediated methane and sulfur cycling in pockmark sediments of the Gdansk Basin, Baltic Sea. Geo-Mar Lett 30(3-4):439-448

Phelps AD, Ramble DG, Leighton TG (1997) The use ofa combination frequency technique to measure the surfzone bubble population. JASA 101:1981-1989

Piekarek-Jankowska H (1994) Puck Bay as an area of groundwater seepage (in Polish). Dissertation. Gdańsk University

PIG-PIB, Petrobaltic, Kronos, Geos, Geosfera (consortium) (2008) Strefy perspektywnczne dla występowania złóż węglowodorów (in Polish). In: Anolik P, Karczewska A (eds) Badania geochemiczne południowego Bałtyku pod kątem analizy skażeń geogenicznych i poszukiwań naftowych (in Polish). Polish Geological Institute, Warsaw part II

Piker L, Schmaljohann R, Imhoff J (1998) Dissimilatory sulfate reduction and methane production in Gotland Deep sediments (Baltic Sea) during a transition period from oxic to anoxic bottom water (1993-1996). Aquat Microb Ecol 14(2):183-193

Richardson MD, Davis AM (1998) Modeling methane-rich sediments of Eckernförde Bay. Cont Shelf Res 18(14-15):1671-1688
Rudowski S, Szefler K, Fajfer G (2010) Gas in sediments of Puck Bay (original in Polish: Gaz w osadach dna Zatoki). Geologia i geomorfologia pobrzeża południowego Bałtyku 8:119-130

Saunois M, Bousquet P, Poulter B et al (2016) The global methane budget 2000-2012. Earth Syst Sci Data 8:697-751

Schmale O, Schneider von Deimling J, Gülzow W, Nausch G, Waniek JJ, Rehder G (2010) Distribution of methane in the water column of the Baltic Sea. Geophys Res Lett 37:L12604. https://doi.org/10.1029/ 2010GL043115

Schneider von Deimling J, Greinert J, Chapman NR, Rabbel W, Linke P (2010) Acoustic imaging of natural gas seepage in the North Sea: Sensing bubbles controlled by variable currents. Limnol Oceanogr Methods 8(5):155-171. https://doi.org/10.4319/lom.2010.8.155

Schneider von Deimling J, Weinrebe W, Tóth Z, Fossing H, Endler R, Rehder G, Spieß V (2013) A low frequency multibeam assessment: Spatial mapping of shallow gas by enhanced penetration and angular response anomaly. Mar Pet Geol 44:271-222. https://doi.org/10. 1016/j.marpetgeo.2013.02.013

Schoell M (1988) Multiple origins of methane in the Earth. Chem Geol 71:1-10. https://doi.org/10.1016/0009-2541(88)90101-5

Schubert CJ, Durisch-Kaiser E, Klauser L et al (2006) Recent studies on sources and sinkds of methane in the Black Sea. In: L Neretin (ed) Past and Present Water Column Anoxia. Nato Science Series: IV: Earth and Environmental Sciences 64:419:441. Springer, Dordrecht. https://doi.org/10.1007/1-4020-4297-3_16

Schüler F (1952) Untersuchungen uber die Machtigkeiten von Schlickschichten mit Hilfe des Echographen (In Deutsch). Deutsche Hydrographische Zeitschrift 5:220-231

Sills GC, Wheeler SJ (1992) The significance of gas for offshore operations. Cont Shelf Res 10:1239-1250

Sorokin OG, Lein AY, Balanyuk IE (2001) Thermodynamics of oceanic hydrothermal systems and abiogenic methane generation. Oceanology 41:861-909

Suplińska MM, Pietrzak-Flis Z (2008) Sedimentation rate and dating of bottom sediments in the Southern Baltic Sea region. Nukleonika 53(2):105-111

Szczepańska T, Uścinowicz S (1994) Geochemical atlas of the southern Baltic (in Polish). Pol. Geol. Inst. Warszawa pp 1-55

Tegowski J (2002) Acoustical recognition of the bottom sediments in the southern Baltic Sea. Revista de Acustica 33

Tegowski J (2005) Acoustical classification of the bottom sediments in the southern Baltic Sea. Quternary International 130:153-161. https://doi.org/10.1016/j.quaint.2004.04.038

Tęgowski J, Zieliński A (2006) Synthesis And Wavelet Analysis Of SideScan Sonar Sea Bottom Imagery. Hydroacoustics 9:199-208

Tęgowski J, Jakacki J, Klusek Z, Rudowski S (2003) Nonlinear Acoustical Methods in The Detection of Gassy Sediments in the Gulf of Gdańsk. Hydroacoustics 5-6:151-158

Thiessen O, Schmidt M, Theilen F, Schmitt M, Klein G (2006) Methane formation and distribution of acoustic turbidity in organic-rich surface sediments in the Arkona Basin, Baltic Sea. Cont Shelf Res 26(19):2469-2483

Thomsen TR, Finster K, Ramsing NB (2001) Biogeochemical and Molecular Signatures of Anaerobic Methane Oxidation in a Marine Sediment. Appl Environ Microbiol 67(4):1646-1656.

Toth Z, Spiess V, Jensen J (2014a) Seismo-acoustic signatures of shallow free gas in the Bornholm Basin, Baltic Sea. Cont Shelf Res 88:228-239

Toth Z, Spiess V, Mogollon JM, Jensen JB (2014b) Estimating the free gas content in Baltic Sea sediments using compressional wave velocity from marine seismic data. J Geophys Res Solid Earth 119: $8577-8593$

Treude T (2003) Anaerobic oxidation of methane in marine sediments. Dissertation, Univeristy of Bremen

Ulyanova M, Sivkov V, Kanapatskij T, Sigalevich P, Pimenov N (2012) Methane fluxes in the southeastern Baltic Sea. Geo-Mar Lett 32(5): 535-544. https://doi.org/10.1007/s00367-012-0304-0 
Ulyanova M, Sivkov V, Kanapatskij T, Pimenov N (2014) Seasonal variations in methane concentrations and diffusive fluxes in the Curonian and Vistula lagoons, Baltic Sea. Geo-Mar Lett 34(2): 231-240. https://doi.org/10.1007/s00367-013-0352-0

Uścinowicz S (1995) Quaternary thickness In: Mojski JE, Dadlez R, Słowanska B, Uścinowicz S, Zachowicz J (eds) Geological atlas of the southern Baltic, 1:500 000. Pol. Geol. Inst., SopotWarszawa, pp 1-63. (in Polish)

Walree PA, Tegowski J, Laban C, Simons DG (2005) Acoustic seafloor discrimination with echo shape parameters: A comparison with the ground truth. Cont Shelf Res 25(18):2273-2293. https://doi.org/10. 1016/j.csr.2005.09.002

Weber TC, Mayer L, Jerram K, Beaudoin J, Rzhanov Y, Lovalvo D (2014) Acoustic estimates of methane gas flux from the seabed in a $6000 \mathrm{~km} 2$ region in the Northern Gulf of Mexico. Geochem Geophys Geosyst 15:1911-1925. https://doi.org/10.1002/ 2014GC005271

Weschenfelder J, Corrêa I, Salvador A, Carla P, Vasconcellos VEB (2006) Shallow gas accumulation in sediments of the Patos Lagoon, Southern Brazil. Anais da Academia Brasileira de Ciências 78(3): 607-614. https://doi.org/10.1590/S0001-37652006000300017

Westbrook GK, Thatcher KE, Rohling EJ et al (2009) Escape of methane gas from the seabed along the West Spitsbergen continental margin. Geophys Res Lett 36(15):L15608. https://doi.org/10.1029/ 2009GL039191

Wever TF, Fiedler HM (1995) Variability of acoustic turbidity in Eckernförde Bay (southwest Baltic Sea) related to the annual tem- perature cycle. Mar Geol 125:21-27. https://doi.org/10.1016/00253227(95)00054-3

Wever TF, Abegg F, Fiedler HM, Fechner G, Stender IH (1998) Shallow gas in the muddy sediments of Eckernförde Bay, Germany. Cont Shelf Res 18:1715-1739. https://doi.org/10.1016/S0278-4343(98)00055-7

Whiticar MJ (1982) The presence of methane bubbles in the acoustically turbid sediments of Eckernförde Bay, Baltic Sea. In: Fanning KA, Manheim FT (eds) The dynamic environment of the ocean floor. Lexington Books, Lexington, pp 219-235

Whiticar MJ (2002) Diagenetic relationships of methanogenesis, nutrients, acoustic turbidity, pockmarks and freshwater seepages in Eckernförde Bay. Mar Geol 182(1):29-53. https://doi.org/10. 1016/S0025-3227(01)00227-4

Wilkens RH, Richardson MD (1998) The influence of gas bubbles on sediment acoustic properties: in situ, laboratory, and theoretical results from Eckernförde Bay, Baltic sea. Cont Shelf Res 18(14): 1859-1892. https://doi.org/10.1016/S0278-4343(98)00061-2

Witek Z, Ochocki S, Maciejowska M, Pastuszak M, Nakonieczny J, Podgórska B, Kownacka JM, Mackiewicz T, WrzesińskaKwiecień M (1997) Phytoplankton primary production and its utilization by the pelagic community in the coastal zone of the Gulf of Gdańsk (southern Baltic). Mar Ecol-Prog Ser 148:169-186. https:// doi.org/10.3354/meps 148169

Witek Z, Ochocki S, Nakonieczny J, Podgórska B, Drgas A (1999) Primary production and decomposition of organic matter in the epipelagic zone of the Gulf of Gdańsk, an estuary of the Vistula. ICES J Mar Sci 56:3-14 